\title{
Allées in Landscape Architecture and Garden Art-Types, Preservation, and Renewal of the Living Heritage of Baroque Allées in Hungary
}

\author{
Kinga Szilágyi ${ }^{1, * \mathbb{D}}$, Chaima Lahmer ${ }^{2}$ and Krisztina Szabó ${ }^{1}$ \\ 1 Department of Garden and Open Space Design, Faculty of Landscape Architecture and Urbanism, \\ Szent István University, 2100 Budapest, Hungary; Szabo.Krisztina@tajk.szie.hu \\ 2 Doctoral School of Landscape Architecture, Szent István University, 2100 Budapest, Hungary; \\ chaimalahmer@gmail.com \\ * Correspondence: Szilagyi.Kinga@tajk.szie.hu; Tel.: +36-302974092
}

Received: 20 July 2020; Accepted: 18 August 2020; Published: 20 August 2020

\begin{abstract}
Examining the history of garden art since ancient times, we find many examples of linear tree layouts supporting orientation or being used for the purpose of composition. Allées gained special significance during the Baroque as dynamic and grandiose space-forming garden design elements. They mostly consist of trees of taxonomically similar species planted along a regular line equidistant from each other in single or multiple rows. The two-dimensional compositional elements of the layout form three-dimensional longitudinal space forms. During their evolution, both their proportions and openness constantly change. Analyses of the compositional role and functions of allées of exemplary Hungarian Baroque garden complexes in the 18th century provided a basis for setting up a novel typology. Five compositional types have been defined as the primary result of archival research. The significance of the still-subsisting historic Hungarian allées calls for unique protection similar to European heritage protection. Taking a summary of significant, surviving examples of Hungarian Baroque allées into account, methods for allée renewal are defined along with the core question of whether allées are natural landscape elements or strict architectural compositions where authenticity may be an important criterion. The methodological research is partially based on three plans for the renewal of Baroque allées in Hungary that have been worked out by the Author as the chief landscape architect of the projects.
\end{abstract}

Keywords: Baroque garden art; allée; European garden heritage; preservation and renewal of living heritage

\section{Introduction}

"Allées have very strong architectural effects, like colonnades or the vaults of buildings. They have intense drift compelling us to pass on, to move on or to look along the line as far as the terminus."(Imre Ormos) [1] [A1].

Planting allées that provide a virtual and visual connection and support spatial orientation was an integral part of the antique Greek settlement culture [A2]. The location of the temenos was offered by nature in the form of a shady grove where a sacrificial altar was raised, and it was linked to the town by the allée planted using trees from the natural tree canopy (Ulmus sp. Olea europea, Quercus sp.) as if representing the connection between the town and the gods. "In Athen's agora, for example, in correspondence with the temple of Hephaestus, there was a geometrical garden, in which the rows of small trees repeated the setting of the temple's columns" [2] (p. 11). According to Vitruvius (a Roman architect, first century BC), trees are appropriate for providing refreshment to the eyes and 
body, and he suggests that promenades be built among the trees leading towards the spas and along the sport-grounds and public spaces.

Besides the examples from early cultures, in Renaissance garden art allées provided the vertical framework for the plane surface parterres along the esplanades, on the bordering of the parterres, and offered pleasant shade to walkers. In the second half of the seventeenth century, André Le Notre, the head royal gardener of Louis XIV of France, went beyond the scale and the local space system of Renaissance gardens and brought together the vistas, the surrounding landscape, the game parks, and the individual royal estates into a cohesive system. This new garden art style, called the French formal garden, visualized the ruling power, among other things, by applying allées. Going beyond the scale of gardens, allées played an important compositional and representational role in the union of architecture, garden art, and landscape architecture. Later, in landscape gardens, allées were integrated as spatial and compositional elements preserved from earlier periods of garden art.

In Hungary, Baroque architecture and garden art appeared only in the 18th century after the Treaty of Karlowitz (1699)—closing the Habsburg-Ottoman War (1683-1697)—brought an end to 150 years of Turkish rule in the Hungarian Kingdom. In the early 1700s, late-Renaissance garden art was gradually replaced by the Baroque representative space structure, thereby giving a more prominent compositional role to the framing allées of gardens, the spatial accessories of hunts with rifles, and the allées of game parks featuring grid networks or star vue systems. The significance of the surviving Baroque allées from the 18th century is strengthened by the fact that no Hungarian Baroque garden has fully lived through the stylistic changes of garden art. In some cases, though, parts of Baroque composition, such as allées, have been preserved in their original form.

The aim of the present research is to define the unique features and significance of allées in Baroque garden art in terms of improvements to the land of noble Hungarian estates. Similarly, in European garden art, the application of allées was well-known to have occurred historically in Hungary based on professional German and French literature, personal visits, horticultural relationships, horticultural studies, and invited gardeners and garden designers. However, gardens and pieces of architectural landscape art are not copies-this would not even be possible because of the living material and the diversity of the landscape and ecology. Therefore, beyond the principles of planning and design, special and unique solutions are created that embody distinctive values of historical European garden heritage.

Based on a historical analysis and classification, the objective of this research is to determine the significance of surviving Baroque allées under heritage protection and facilitate the preservation and renewal of these allées by proposing a new heritage protection task and method.

The living heritage of subsisting late-Baroque allées captures glorious memories of bygone times and has special value throughout Europe. The mature trees lined up in the allées with their respectable size in themselves have a high degree of aesthetic and natural value, and even their genetic heritage may have scientific importance. Moreover, allées are planned and constructed open-air creations that represent cultural heritage.

\section{Materials and Methods}

The basis of this research was provided by decades-long, research-based, reconstruction-type planning projects for several historic Hungarian gardens and allées [3,4] [A3,A4] together with references found in the scientific literature on Baroque garden art [1,5-7], which, in certain cases, was expanded by field research, surveys, and studies of sources. In terms of references, the primary guide was Kristóf Fatsar's monograph entitled Magyarországi barokk kertmúvészet (Hungarian Baroque Garden Art), which is a rich mine of knowledge of the Baroque gardens of historical Hungary. The analyses of garden art history and detailed garden treatises were based on in-depth archival research, cartographical and image sources, historical garden descriptions, and documents found in national and family archives [8]. In many cases, earlier historical garden studies [9-14] and historic cartographical archives provided further assistance. I went to sources of international scientific 
literature mostly to lay down the theoretical and methodological foundations of Baroque garden art and, in particular, allée heritage and allée renewal [7,14-16].

Besides the historic maps, archival plans, surveys, and image sources contained in the references used in the present research, military surveys and cadastral maps can offer additional information; however, the correctness and precision of the latter are far from uniform. Nevertheless, historic archives can be efficiently utilized in an investigation of the landscape connections between the core of an estate and its functional elements. After looking at the plans and contour maps of the period, it was also uncertain whether the landscape architectural plan was implemented and, if it was, whether the constructions precisely followed the plan. In terms of a significant Baroque castle garden, in most cases, more than one draft or plan was ordered and made by different masters. However, it is not appropriate to use historic surveys to resolve this issue, because it is the precision and detail of the first military survey of the Habsburg Empire (1782-1785) that are uncertain.

Therefore, this research is based on primary historical references that are already published, their reinterpretation, and, when necessary, further image or written sources. Several heritage protection plans, as well as preservation studies and concepts of living heritage, were added to the original research materials based on detailed assessments and condition analyses of the tree canopy works that were carried out under the supervision of the author as a supervising landscape architect. Some of these site analyses, cadasters, and concept plans have been published [17-21], while the professional studies of and management plans for several Baroque allée heritage sites are listed in the Appendix A (A3a-d).

\section{Results}

The nearly 150 locations of creations of Baroque garden art published in Hungarian and considered to be the primary sources for this research [8] represent the precise footprints of the development, as well as the social and manorial system, of Hungary in the 18th century. The geographical positions of the valuable Baroque gardens show a highly disproportionate spatial distribution. Due to the geopolitical, economic, and landscape structural conditions, the estates of wealthy noblemen were mostly developed in the western and north-western regions of the Hungarian Kingdom, in the vicinity of the center of the Habsburg Monarchy, Vienna, and close to Bratislava (called Pozsony in Hungarian), the venue of the feudal assembly, which is considered to be the predecessor of the parliament. The Baroque foci of Budapest ("Pest-Buda" at the time) and its neighborhood, Northern Hungary, and Transylvania are scarcer, while, on the lowlands of the country, in the middle region, and partly in the eastern regions, only a couple of relevant large estates flourished from the end of the 17th century (Figure 1a,b). Transylvania had a certain degree of independence-as the Principality of Transylvania-during the difficult times of Turkish rule and retained the power of self-government after the unification of the country, which was effected by the House of Habsburg. The development of the noble estates was almost uninterrupted here, although, due to the isolation, the geographical position, and the Protestant opposition to the Baroque that was deeply rooted in the resurgence of Catholicism during the 18th century, Baroque castle architecture and garden art gained space only slowly, and even with a delay, and while it retained local architectural traditions it received a distinctive and somewhat provincial character. The geographical features of the landscape, the varied topography, and the large afforested areas also contributed to this. High-quality baroque castle gardens could only be developed by wealthy members of noble society, either secular or ecclesiastical, with good political connections or a profitable court status. 


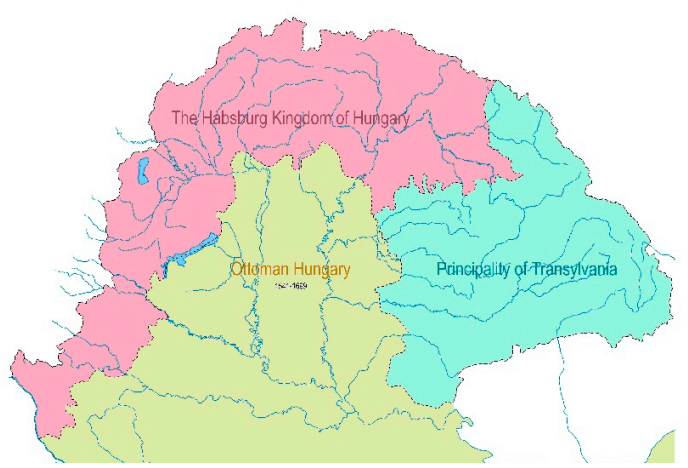

(a)

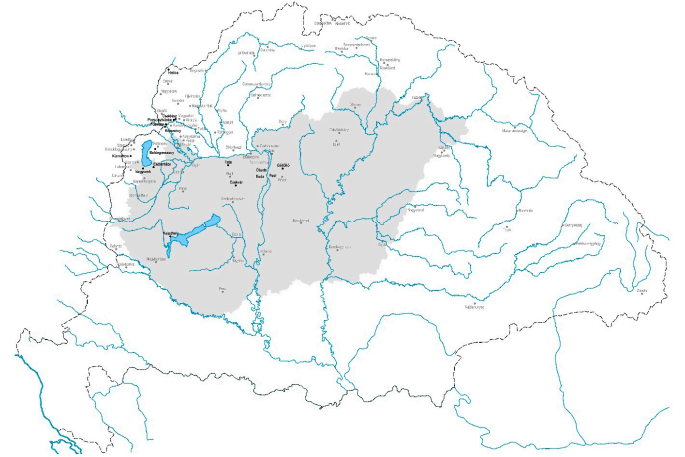

(b)

Figure 1. (a) Map of the former Hungarian Kingdom. The country was divided into three parts due to the Ottoman occupations. 1606. (b) Hungary in the 18th century with valuable Baroque estates and castles. The territory marked in grey is the result of the 1920 Trianon decision (Sources of figures see in Appendix B).

\subsection{Classification of Allées Based on Spatial Function}

Within the published historical sources, maps, and archives used as references for the research, in terms of the discussed Baroque gardens, one can find allées that are planted in single, double, or multiple rows, and they may have simple or complex compositional or practical functions. In many cases, it is possible to derive from the survey maps, garden design plans, historical images, or archival sources the order of the allées in the plantation system, the utilization of the internal and external esplanades, and the unique or sectional accentuation of the rhythmical mini-spaces and their ornamentation by statuary, garden seats, or flowerbeds calling visitors to take a rest. The plantation material and the punctual planting pattern are also important aspects. However, what may have even greater importance than these garden art details is the exact location of the allées within the estate and their connection to architectural units, gardens, open spaces created by natural elements, and external areas, which indicate relatively easily readable or visible functions. According to the compositional and functional goals, five main types can be differentiated. Naturally, there are certain grandiose or unique Baroque creations that are difficult to strictly insert into this categorization or that include more than or even all of the five allée types within the same piece of art.

\subsection{Analyses of Hungarian Baroque Allées Based on Architectural Compositional Aspects}

For each type, we present the prominent examples of Hungarian Baroque garden art. The more complex the compositional task of the allées, the more often does the same location occur when describing the types. It is also important to note that the 18th century was a late-Baroque period in Hungary. Many allées were created during this period and some of them-with mature or even veteran trees in their stock—survived to the present.

\subsubsection{Allées Connected Directly to the Building Complex of the Estate}

According to the published sources, layout plans, and maps, allées relatively rarely appear solely as space-forming, focus-formation elements connected directly to an edifice or a building complex. These allées accentuate the architectural pieces and rather frequently indicate the connection with the garden or the vue de point in the landscape and the organic union of architecture and garden art. Two examples of the first subtype and one of the second are introduced here.

The plans for the reconstruction of the garden of the Esterházy Castle in Csákvár started in the last third of the 18th century [8]. The 1779 plan, that of Ehrenberg, depicts the foreground of the castle as an open entrance space formed by strictly symmetric, double-row allées, where the spacious, oval entrance space - in front of the closed, horse-shoe-shaped ornamental yard-is framed by an allée equivalent to the width of the yard. Along the longitudinal and cross axes, ways are bordered by 
double allées (Figure 2). The plan delineates the ornamental garden as an early English, irregular garden in which the Baroque symmetry is loosened, and only the two inclined roads leading out from the garden accompanied by allées remind us of the Baroque structure.

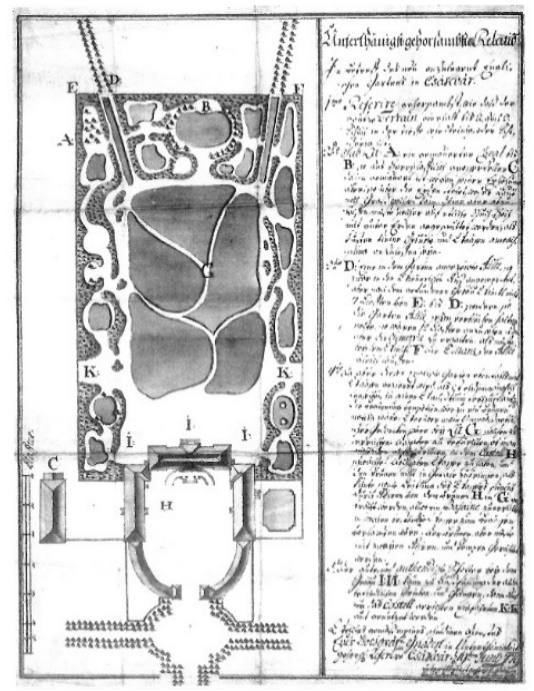

Figure 2. Ehrenberg's plan of Esterházy castle in Csákvár together with the early English garden and the Baroque foreground. 1779.

The plan of the double-rowed, framing allée running along the four sides of the yard of the Esterházy Manor in Boldogasszony (Frauenkirchen, Austria) dates back to the second part of the 18th century (Figure 3). Its peculiarity lies in the fact that, although the main building and the two lateral farm buildings have different facade rhythms and distributions, still, on all four sides, the allée follows the same plantation rhythm adjusted to the main building. Although the author of the monograph on Hungarian Baroque gardens regards this issue as sort of a planning mistake [8] (p. 82), we consider it to be more likely that this solution, which might have a slightly disadvantageous effect on the utilization of the auxiliary buildings, could have developed as a result of the strict stiffness of Baroque space structure. The balanced rhythm and the continuously identical plantation distance impart a stiff character to the yard, and the emphasis is clearly placed on the main building.

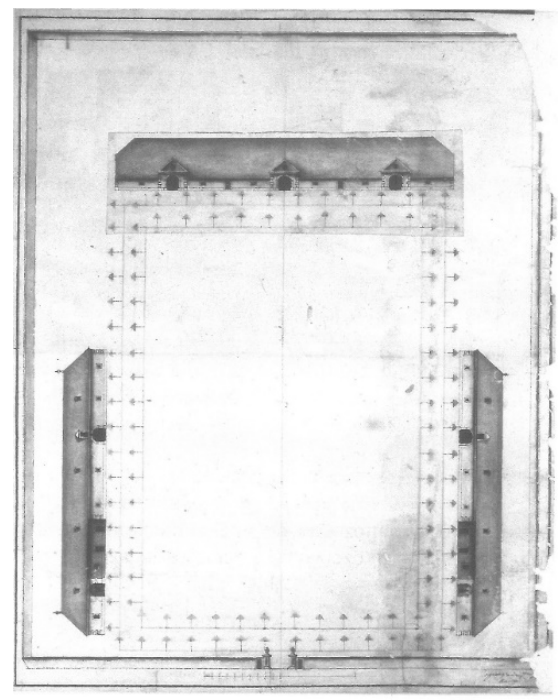

Figure 3. Boldogasszony-the tree plantation plan for the Esterházy prince's manor's courtyard. Plan of Johann Georg Weinstein. mid-18th century. 
An allée encompassing a palace and a fortified castle as a protective circle can be found at different locations. The Habsburg-Lotharingen castle in Holic (Holic, Slovakia) is a star fort castle with a square layout that is surrounded by single-rowed allées on both sides of the moat [8] (p. 121). The fortified castle in Köpcsény (Kittsee, Austria) is a similar star fort castle with a square shape that is also enclosed by an allée. The Esterházy Palace at Süttör (now Fertőd, Hungary) can be partly classified as belonging to this group too, where the depictions of the garden from the second part of the 18th century show a double allée bordering the building complex; however, here, the allées have a more composite, perspective function.

Eszterháza, the grandiose and mature Baroque masterpiece called the Hungarian Versailles, is a uniquely gorgeous and complex creation in terms of its application of allées (Figure 4a,b). In addition to these exemplary sites, we could also mention the Károlyi Castle in Nagykároly and the silk manufacturing building in Óbuda, where allées have been planted to create stress, a framing, or a landmark in front of or around the building.

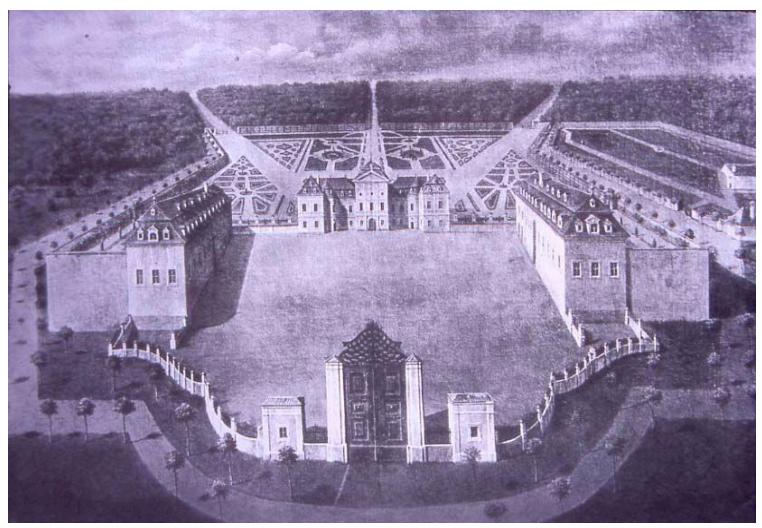

(a)

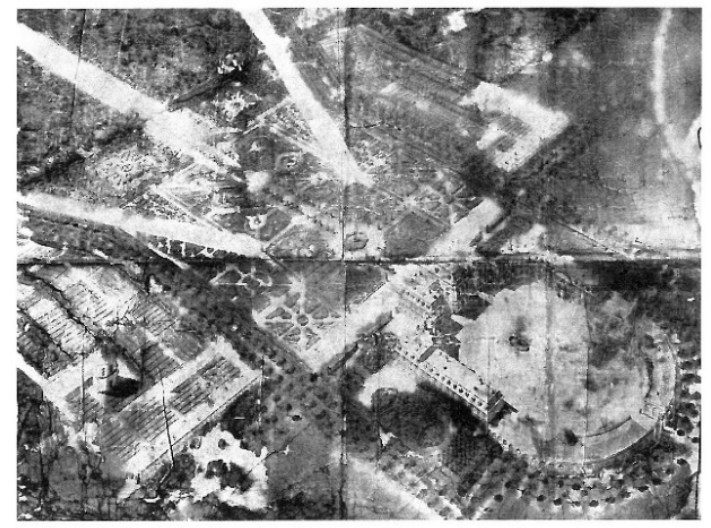

(b)

Figure 4. (a) View of the Esterházy Castle from the North. Oil painting, around 1760 [10]. (b) The bird's eye view masterplan for the Esterházy castle in Fertőd. Girolamo Le Bon, around 1762 [10].

\subsubsection{Garden Allées: Along the Garden Paths Marking the Axis or Framing Parterres}

Framing allées in Baroque gardens—on the bordering of parterres (or "patches")—“inherited" from the Renaissance are also characteristic, but the strongly marked elements of the composition are provided by visual axes revealing perspectives as well as allées planted in order to visualize and emphasize the longitudinal and cross axes, vues radiating from the connection system, and the scale of the estate. This is also relevant even if the garden directly connecting to the castle is not an ornamental or pleasure garden that serves as a form of representation but is an orchard, a kitchen garden, or, perhaps, a grapery.

The fundamental garden art motif, which dates back to the ancient Persian gardens [A5], consists of four patched gardens divided by two axes and stressed by a well or a fountain that is located in the intersection of the axes, which refers to the four directions, with a vertical stress point in the central space to represent the connection with the sky [1,5]. In the Baroque period, the allées bordering the parterres functioned as means of opening up perspectives in a way that provided the garden's axes with a dynamic leader. With the help of the allees, the spatial system of the garden definitely stands out in the third dimension too, and, besides the garden, the bosque of trees, and the game parks, they frequently direct the eyes towards the distant landscape, creating a feeling of an endless empire.

We can observe the application of a characteristic space-bordering and framing ornamental garden allée in the Baroque upper garden of the Grassalkovich Castle in Gödölló. During the archival research [8], we found three alternate garden plans from the mid-18th century, created by unknown planners (Figure 5). The longitudinal garden with a rectangle layout presents the main elements of the ornamental garden one after another: the flower and grass parterres, the bosque of trees [A6] enclosed 
by high hedges, the ornamental water feature, the kiosk, and the open, wide central axis. Typically, the longitudinal side is closed by double allées of densely planted trees.
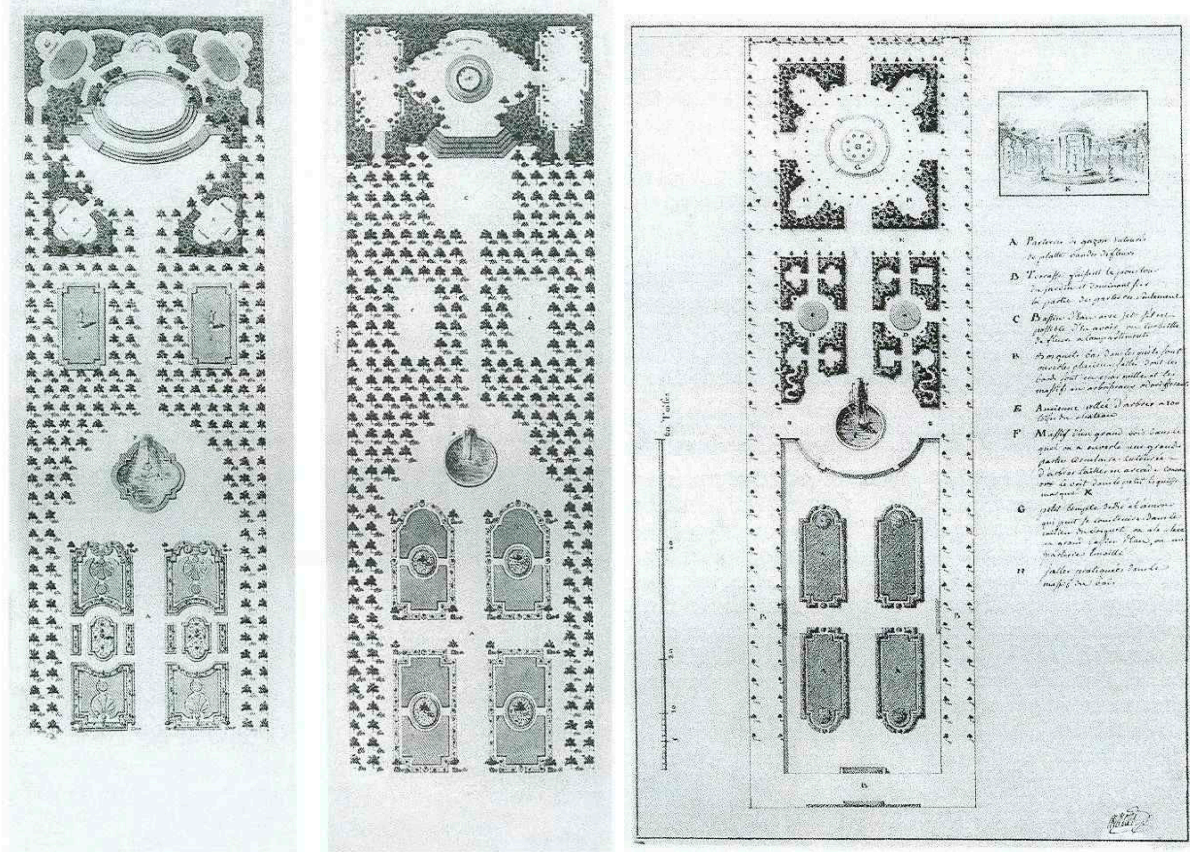

Figure 5. The alternate designs 1 and 2 for the upper garden of the Grassalkovich Castle in Gödöllo and design 3 by Andreas Kneidinger, which was supposed to have been implemented in the mid-18th century.

The third variant is from a French designer and, according to the onetime garden descriptions [A7], this plan could have been implemented. The double allée on the two longitudinal sides frames a spacious esplanade. Both the allées and the esplanade take a turn at the end of the garden, but they leave the central axis open to the landscape throughout the full length of the garden. The application of the allée in its framing function appears at the back quarter of the garden, where, along the longitudinal central axis and the cross axis, the forest-like bosque is divided into four symmetric space quarters. On the elevated podium in the central space stands a kiosk, formally a domed gloriette, and a double allée that closes around it like an arbour provides shelter.

The peculiarity of the allée in Gödölló is attributed to the fact that out of the two double allées-notwithstanding the successive reconstructions of the garden-the western allee and the esplanade have survived into the present in order to provide shelter to and a spatial boundary for the internal, pleasure garden part of the chateau's garden that was expanding its area and functions [18]. The set of reconstruction-type renewal plans [A3a-d] for the Gödöllo upper garden placed great emphasis on reviving the horse chestnut allée (Aesculus hippocastanum) dating back to the Baroque period $[17,18]$.

The urban garden of Bratislava, Enger Au or Brucken $\mathrm{Au}$, is considered to be an early example of an urban public garden and was created on one of the wooded islands on the right side of The Danube between 1775 and 1776 [8] (p. 196). This public garden, which is accessible from Bratislava via a pontoon bridge, is a forest featuring a star vue system where the wide axial clearings serve walking rather than hunting (Figure $6 a, b)$. The esplanade, which has eight axes that all converge into a central space accentuated by a solitaire tree and equipped with lawn benches, is laid out by eight different tree species in the allées in order to help with orientation in the densely wooded floodplain forest. Therefore, the garden, both in its character and its design, resembles a game park, but the planting design of the allées helps visitors seeking recreation to safely orient themselves. 


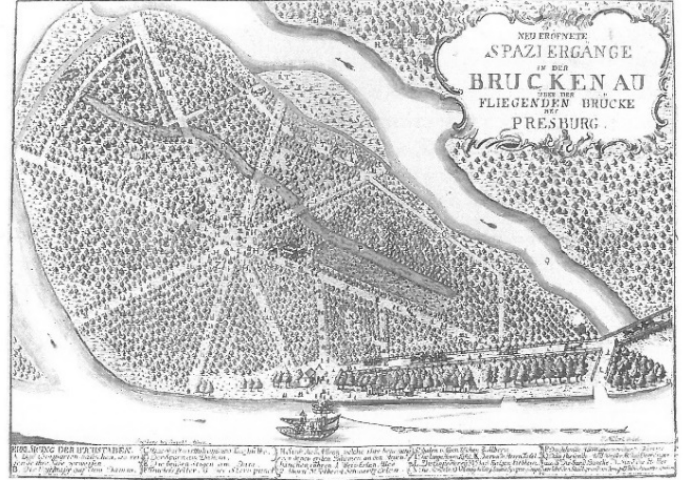

(a)

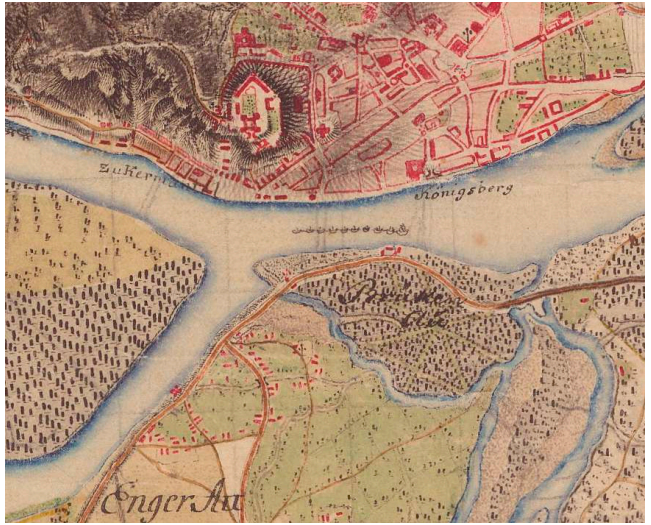

(b)

Figure 6. (a) Urban public garden of Enger Au/Brucken Au in Bratislava. Creator unknown. Around 1775. (b) The urban park is a small woody island among the Danube branches with a star-form avenue system.

Eszterháza, a late Baroque-Rococo garden complex, is the masterpiece of the 18th century. Based on the surviving plans and depictions, this magnificent ensemble of gardens, a bosque or game park [A5], and hunting forests was planned and developed throughout four decades under the guidance of Prince Miklós Esterházy on the fundamentals of a Renaissance hunting lodge and wood [11]. In terms of typical Baroque gardens, allées were applied with a framing and closure-forming function, but the bordering ones on the two sides of the ornamental garden in front of the castle are unique. Nicolaus Jacoby's 1784 drawing, which delineates the so-called Beschreibung [11], shows triple allées [A8] on both sides that mark esplanades of identical widths. The allées, which consist of lime and horse chestnut trees planted in a $4^{*} 4$ fathom order, offer an arbour-like closed path (pruned in the Berceaux form). They are parallel to the transverse axis along with the ornamental garden. Then, at the last ornamental parterre, they break into the direction of the two inclined side-axes of the goosefoot esplanade and terminate at the lateral axis that closes the ornamental garden and opens up the game park with wide hunting avenues. Although replanted, mixed both in tree species and age, and having many hiatuses in the rows, these allées remain standing even though the onetime arbour-like, dome-enclosed space form created by pruning is gone.

\subsubsection{Allées of Game Parks: Allées in Vues Supporting Orientation}

The estates of noble society have always had game parks or hunting forests with an artificial, planned vue system formed out of the tree canopy of natural forests [A9] that frequently stretched out to multiple hectares [A10]. As opposed to the intensive horticultural maintenance of an ornamental garden, forestry and hunting types of preservation and maintenance were conducted here. However, within the game parks-mostly with star-vue systems-different garden edifices, pleasure houses, fountains, and pools were built in the green spaces opening up around the intersections of the vues. A game park in this way functions as a closed forest garden or pleasure garden with a dense tree canopy, that is, in other words, a bosque on a large scale. According to the landscape structure, these game parks can be independent elements or an organic extension of the ornamental garden with a definitive tree canopy. In both cases, the allées act as integral connection and uniform design concept elements.

The garden complex of the Grassalkovich Castle in Pozsonyivánka (Ivanka pri Dunaji, Slovakia) is a proper example of a freestanding game reserve, yet it is connected to the castle and the ornamental garden by an allée. The residence built during the second half of the 18th century includes a large pheasant garden that the Fekete-víz ("Black water") river splits into two parts (Figure 7a). The cross axis closing the lawn parterre in front of the castle reaches the pheasant garden with an almost one-kilometer-long double allée that features a complex vue system. The triple goosefoot vues are divided by cross-axes and a star vue system. 


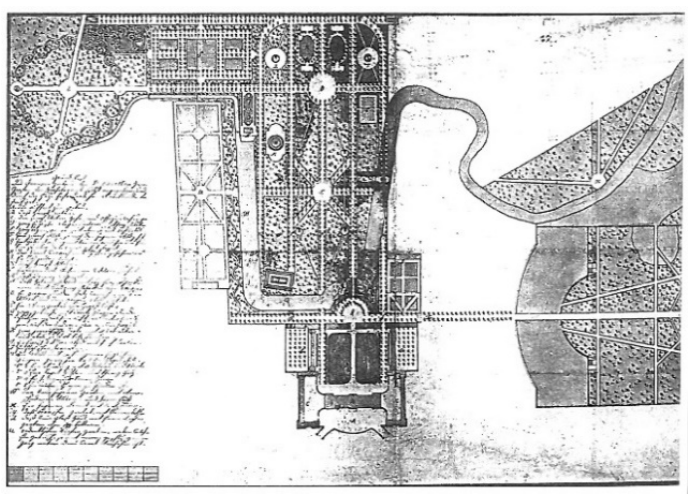

(a)

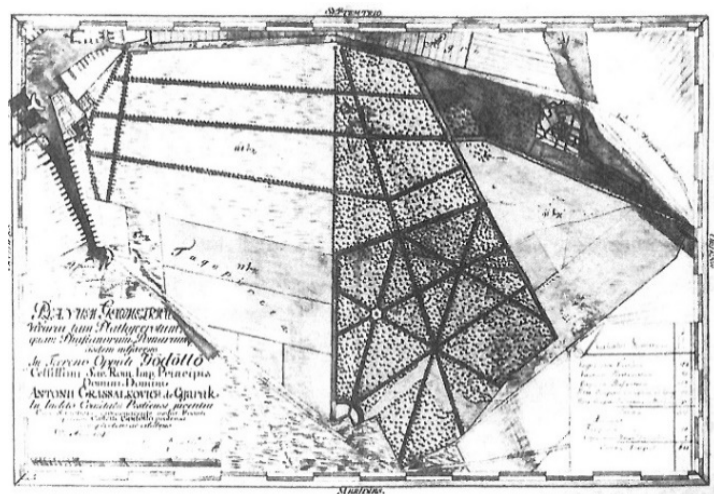

(b)

Figure 7. (a) The Grassalkovits estate in Pozsonyivánka around 1780. The game preserve is connected to the castle by the allée of the lateral axis. (b) The lower garden of the Gödöllo Castle has a complex star-form vue system for hunting and one axial system directing to the castle.

The game reserve of the Grassalkovich Castle in Gödöllő has a similar organization. Here, the game park is located over one kilometer away from the castle due to the landscape conditions. A road accompanied by a double allée leads the way to the game park from the castle. Starting from the semicircular reception area, a composite vue system unfolds into the pheasant garden. The cross-axis is also the middle section of a triple goosefoot vue system, while the two inclined side esplanades constitute the paths of the double-star vue systems [17].

Eszterháza is an example of the type of game park that forms a continuation of the ornamental garden on the highest possible level (Figure $8 \mathrm{a}, \mathrm{b}$ ). The continuous texture of the garden sections is divided by space-bordering, partition allées with cross-axes. The ornamental garden is closed by a cross-axis, framed by a double allée that is opened up with a semicircular exedra symmetrically in the middle of the longitudinal axis of the entire garden complex. The game park is bordered by a double allée path on the two longitudinal sides, and it is closed by another cross-axis as well as a spacious exedra framed by a double allée.

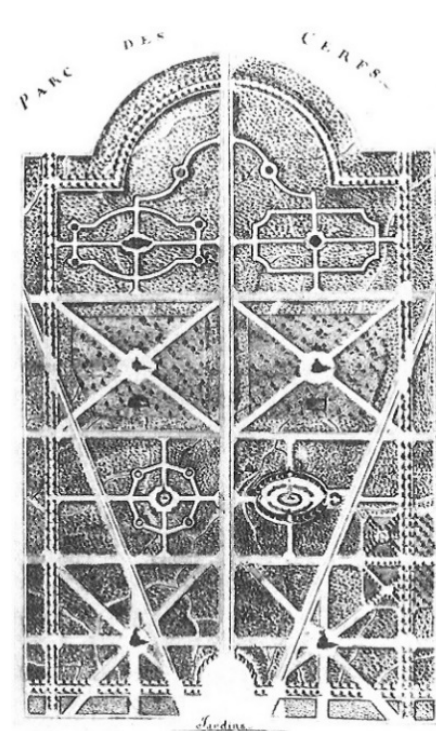

(a)

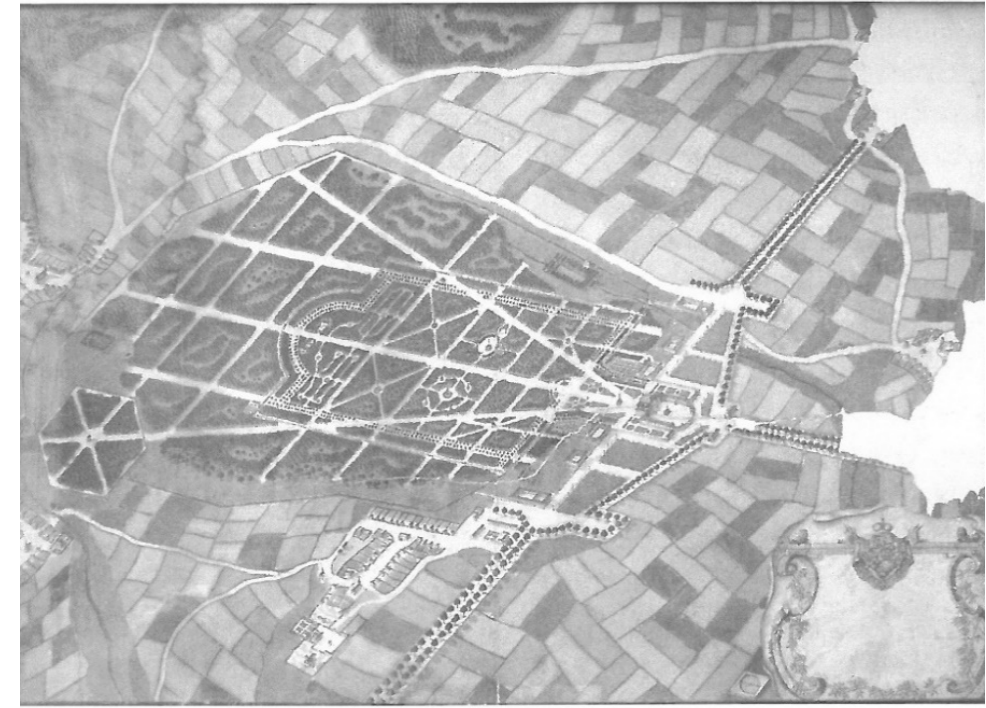

(b)

Figure 8. (a) The game park at Eszterháza. 1763. (b) Bird's eye view painting of Eszterháza's gardens, the game park, and the vue and allée system. 1773. 


\subsubsection{Allées in the Landscape: Independent Compositions beyond the Garden}

These compositions present the organic entity of landscape architecture and formation that, while exiting the border of the castle garden (the center of the estate), reveals the perspectives not only in a visual sense supported by the vue but also in reality. Landscape-scale allées may be located along roads providing direct connections, but they rather enrich the representation in order to more fully achieve the Baroque composition. According to Baroque construction, these are double or, in certain cases, quadrate allées that run as straight as a bowstring until they almost reach the horizon. The middle esplanade is generally covered by lawn. The two side esplanades, the so-called "counter-esplanades", usually have a sprayed lining and serve as a service path.

One of the monumental tree allées of the 18th century is part of the baroque estate of Count Antal Széchenyi at Czenk (now Nagycenk, Hungary) [4]. The construction of the castle together with the first Baroque garden started in 1741. Then, in the 1750s, as a continuation of the Baroque ornamental garden, a double lime tree allée was planted on the opposite side of the main road. It formed a 2.3-km-long linear landmark (Figure 9a,b). The "allée vert", with a $22.7 \mathrm{~m}$ (12 fathom) wide meadow in the central path, consisted of around 600 trees (planted at a distance of $7.6 \mathrm{~m}$ (4 fathoms) in the rows) and directed the main architectural axis far into the landscape to a spectacular viewpoint of the Fertô lake (the Neusiedler lake), where a small grove offered a termination point and the right place for a hermitage and a chapel. Due to the spacious positioning and the Széchenyi family's responsible maintenance into the mid-twentieth century, the allée evolved into a monumental landmark whose natural value was protected in 1942 [13], then it was placed under heritage protection in 2001 as part of the historic garden of Nagycenk and as a landscape element of the Fertőd-Neusiedler World Heritage site. A cadaster from 2011 [A11] defines 581 original planting spots altogether, with around half of the stock probably being rooted in the original plantation and still-living small-leaved lime trees (Tilia cordata). The Széchenyi lime tree allée is a unique heritage site among the Baroque allées, and its renewal with intensive maintenance and tree care together with an authentic renewal project has been started.

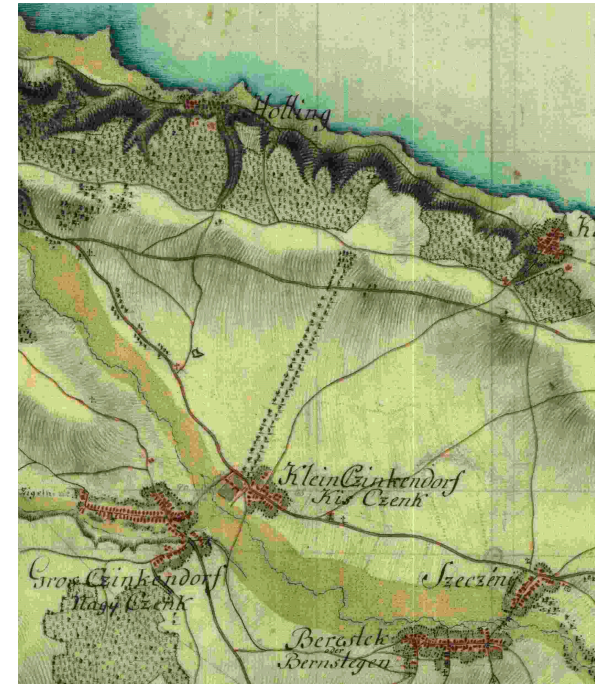

(a)

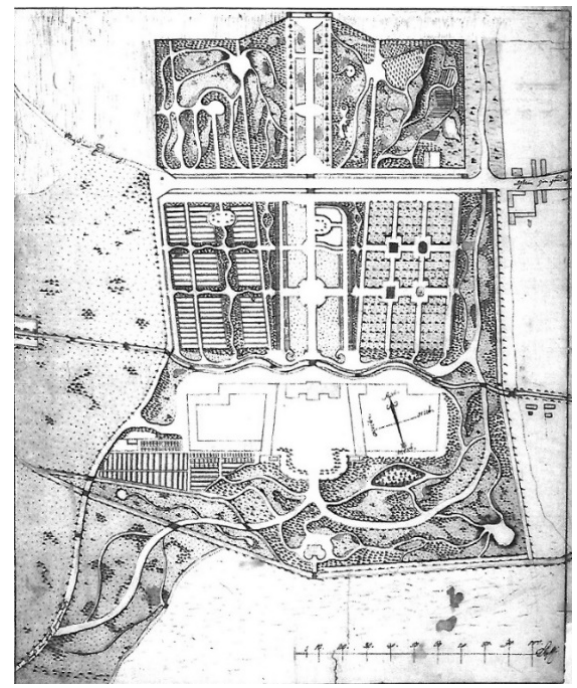

(b)

Figure 9. (a) The Széchenyi estate in Czenk around 1763-1787. (b) The first section of the lime tree allée to the north around 1785-1788.

Lime trees are often used in monumental tree allées, such as the one at Köpcsény (now Kittsee, Austria and Kopčany, Slovakia) belonging first to the Eszterházy family and later to the Batthyány-Strattmann family's estate. The creation of the Baroque garden and the allée was ordered by Prince Esterházy between 1730 and 1740, possibly together with a new allée (Figure 10). The double two-rowed lime 
tree allée stretched out in the north-eastern direction for circa $3 \mathrm{~km}$ from the fortified residential castle. The vista is provided by the castle of Bratislava about six kilometers away [4]. The allée runs almost parallel to the road connecting Köpcsény with the Danube and Bratislava beyond it and stretches out a little west from that until it reaches the floodplain of the Danube. No closing chord can be located on the map (not even the second military survey indicates one), but Enger Au and Brucken Au by the right side of the Danube might have been a nearby recreation target. Following the Treaty of Trianon, the territory was disunited, the hither floodplain of the Danube became a part of Czechoslovakia, and the allée unfortunately fell victim to agriculture. Its "cold trace" in the form of a farm track can still be found. There is no hope for reconstruction, so two lime trees were planted in 1991 as a living memorial to the allée [6].

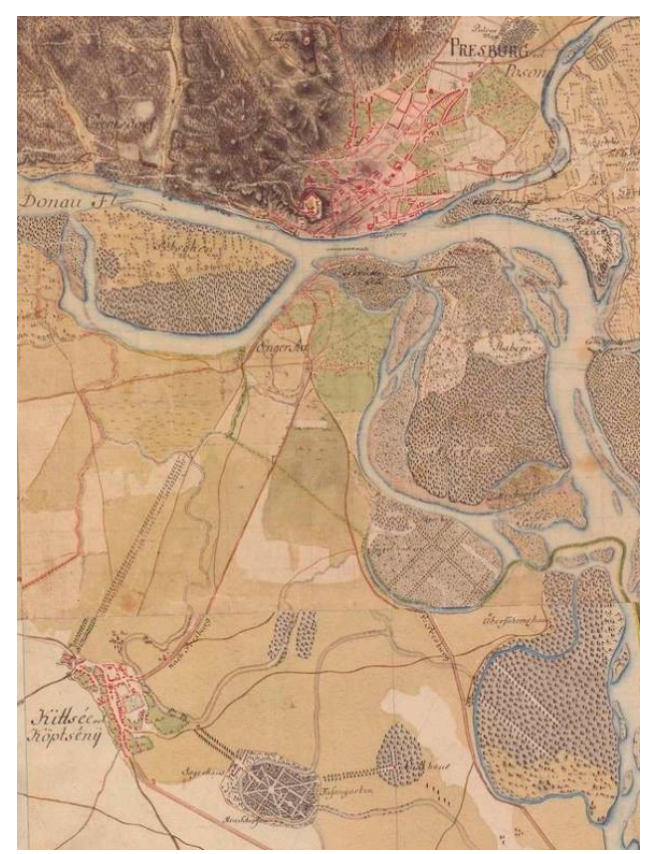

Figure 10. The quadruple lime tree allée in Köpcsény (Kittsee) looking at the castle of Pozsony (Bratislava).

Eszterháza has special value in terms of allées terminating in the landscape. It can clearly be pointed out on the first military survey map (Figure 11) that the longitudinal and cross-axes of the castle garden almost precisely meet at a 90-degree angle, and their directions are marked by the church steeples of Szentmiklós (now Fertőszentmiklós, Hungary) to the south and those of Széplak (now Fertőszéplak, Hungary) to the west. However, the vue de point is missing in Süttör to the east. Yet, for the benefit of Baroque symmetry, the eastern continuation of the cross-axis-at least on a planning level—should have been an important compositional element [12]. Both the bird's eye view depiction from 1773 (Figure 8b) and the Beschreibung from 1784 by Jacoby (Figure 12) indicate that the cross-axis led far into the landscape and was bordered by a double allée.

The Grassalkovich Castle in Pozsonyivánka, which was already mentioned in our discussion of game reserves (Figure 7a), is an interesting example of a landscape-scale allée. An allée that serves as a continuation of the cross-axis to the east leads into the game park, which features a goosefoot vue system and a star vue system beyond the stream, in such a way that the line of the allée proceeds in the middle element of the goosefoot path system (Figure 13). The axial composition terminates at the riverside and directly crosses to the Eszterházy castle at Cseklész. The investigation of this direct linear link marked by allées showed that it serves not only the obvious functions but also as a direct connection between the two noble families that had close relations. It is also important to mention that the middle and western elements of the goosefoot vue system running into the southern game park in Pozsonyivánka have been preserved in the modern settlement structure in the form of streets. 
Only a few examples of allées in Hungary from this period could be mentioned as having this type of allée design. These grandiose, several-kilometer-long garden creations are generally for representation. On the other hand, the landscape structure is a crucial element in such developments. All of the above-listed noble estates lay on plains with a wide and open landscape. Besides Eszterháza, Nagycenk, and Köpcsény, the Esterházy residence in Tata could also be mentioned. The landscape around the fortressed castle at the Tata lake also offered the possibility to create a representative allée along the lakeshore-at least in the plan of Jakab Fellner from 1763 in which a grandiose allée of twin double rows that runs along both directions from the castle is proposed [8] (p. 217).

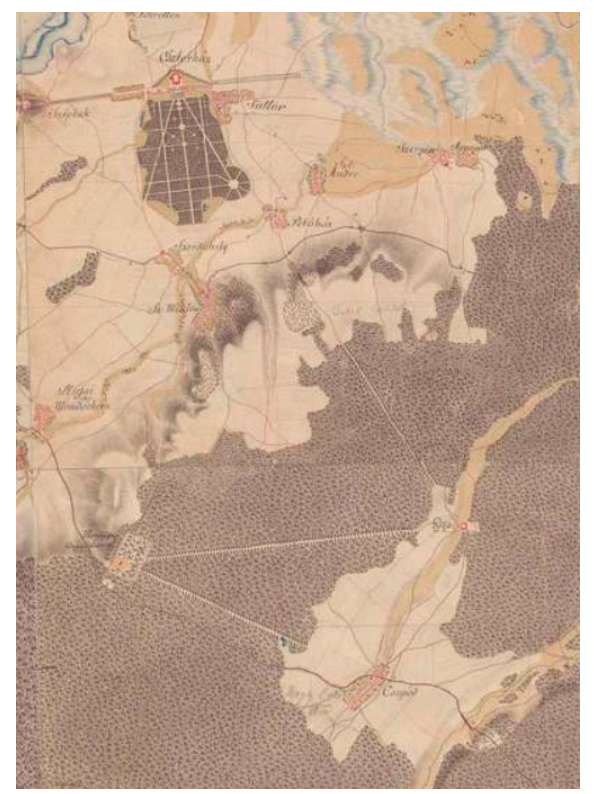

Figure 11. The Eszterháza allée, vue, and focal system in the landscape. The first military survey. 1782-1785.

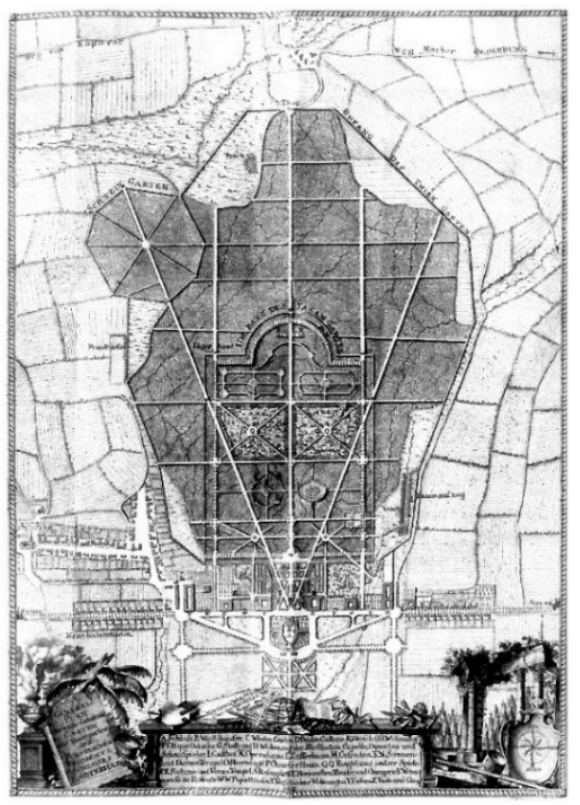

Figure 12. General map of Eszterháza. Engraving of Beschreibung, 1784. Allée on the lateral axis terminates in the neighboring village with the church as an eye-catcher to the west (map oriented to South). 


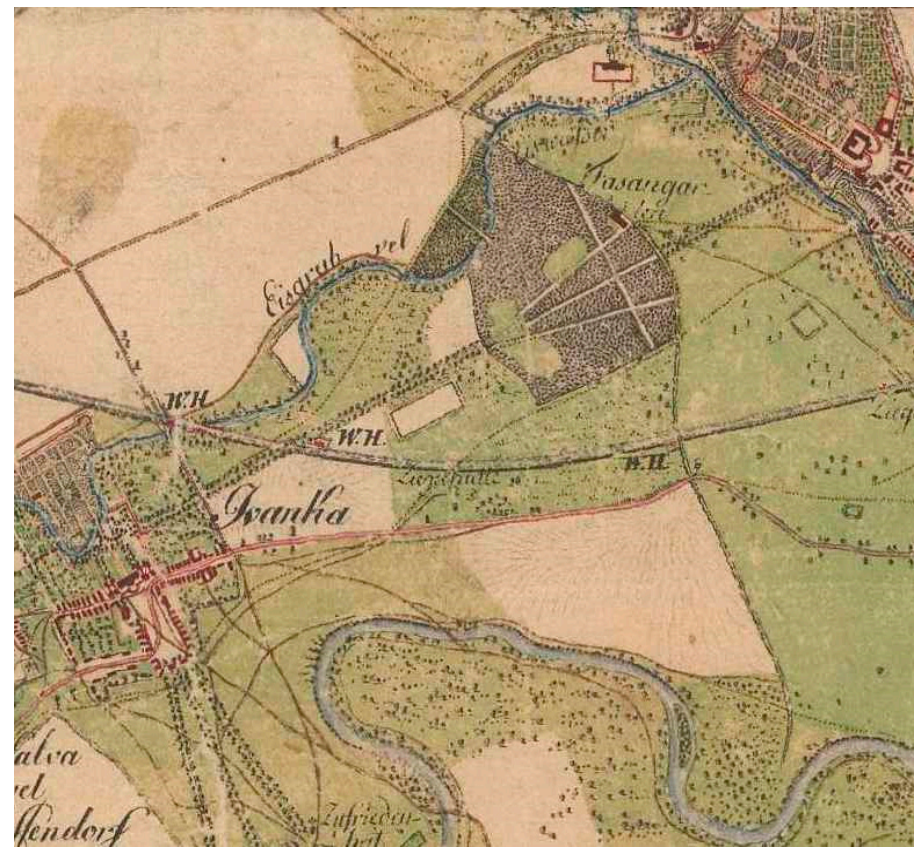

Figure 13. The double allée that runs from Pozsony-. ivánka to Cseklész opens up the game park and links the two estates together. Early 19th century.

\subsubsection{Allées That Mark the Road to the Castle and Assist with Orientation}

Trees planted along the main roads that terminate in an aristocratic residence offer the experience of arrival and a representative welcome to the owner and guests. The allee accompanying the road may lead through the full length of the settlement or even beyond it. In addition to some simple solutions (the Episcopal garden at Eger, the garden of Eszterházy castle at Lakompak, and the archbishop's garden and game park at Pozsony), we must mention Eszterháza here, even though it shows less in terms of afforested roads with a perspective-opening function. According to the Beschreibung of the year 1784 (Figure 12), the road that opens the perspective of the castle leads to the gateway facing north and to the reception courtyard through it. Based on the depiction that was made partially for planning purposes, the road stems straight from Sarród and Fertô lake and is accompanied by an allée. Neither the first nor the second military survey indicate this traffic connection to the north, which is a continuation of the main longitudinal axis of the castle. Therefore, the main access point might still be the road that a double allée follows from the direction of Széplak to the west. This road then breaks to Süttör to the east and runs in front of the watch-houses. According to the rule of symmetry, both roads are afforested by double allées that still exist, at least partially.

The other example is to be found at the western border of Lake Balaton, Keszthely, where Count Kristóf Festetics started to build a castle in 1745. The castle garden was created according to the 1755 plan sheet by Kristóf Hofstädter (Figure 14) based on the traditional French model. A patched parterre garden but no perspective-opening road, vue, or allée can be found here. Allées are used to frame and open the orchard. However, on the first military survey map, a double tree allee along the road can be detected. It is located to the south of the castle and leads to the port and crossing of the lake. The tree allee starts from the Festetics manor with a small castle and large buildings, called Fenékpuszta, which was established at the site of the late Roman fortress called Valcum. 


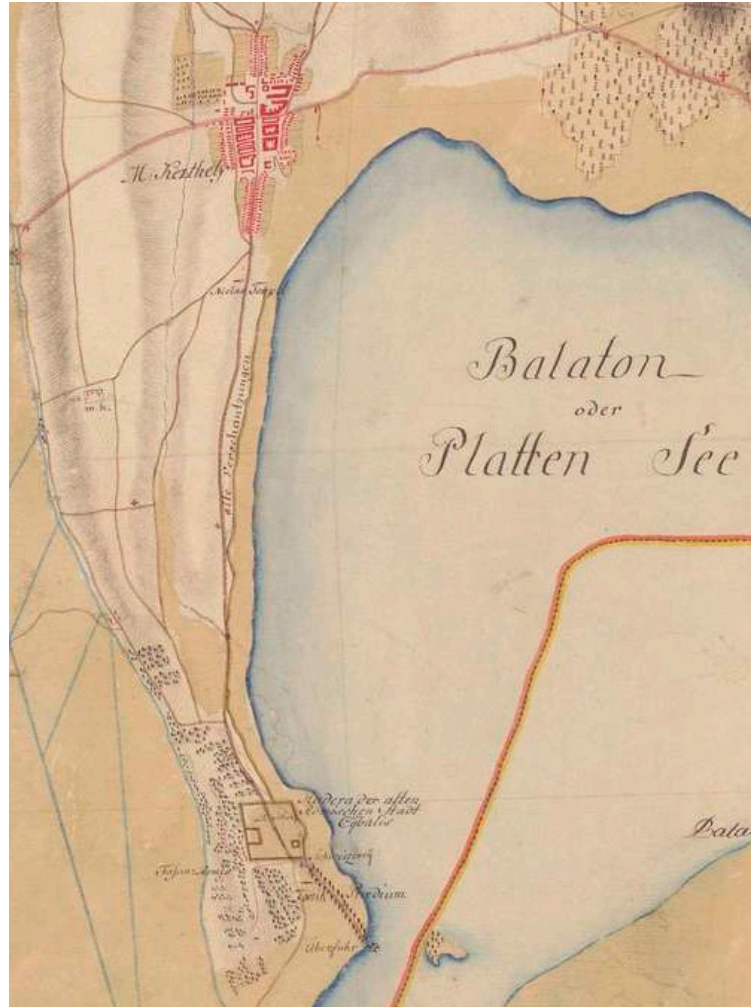

(a)

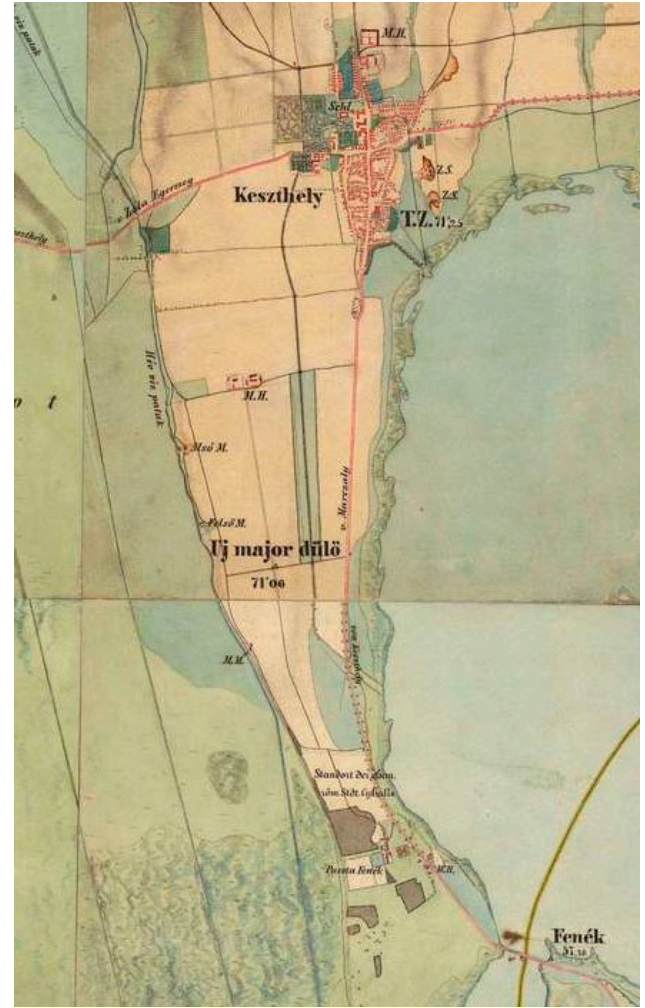

(b)

Figure 14. (a) Keszthely with the Festetics estate and the ancient Roman camp, Valcum, to the south. The port is connected from here with an allee. 1782-85. (b) The link between the castle and the manor at Fenékpuszta is stressed with an allée along the main road. Early 19th century.

However, the famous allée of Keszthely no longer resembles a Baroque allée. Instead, it resembles the age of the mature landscape garden of the end of the 19th century, when Earl Taszilo Festetics planted the road between the termination of the castle garden and the small castle with the stables in Fenékpuszta with a landscape-scaled allée. Compared with the allées that have come down to us from Baroque times, this is a young allée representative of a new era in which the landscape-scale garden elements of the previous Baroque epoch were applied but in a different way. The famous Festetics allée leading to Fenékpuszta is a loosely planted double allée of black pine trees with an open view of the landscape. The almost irregular shape of the crowns of the black pine trees (Pinus nigra) cultivated to grow a high trunk perfectly balances the linear allée's architecture. The Festetics allée is an excellent example of the insertion of the landscape into the age of landscape gardens.

However, this is a new period in the history of garden art and allées have been integrated into rural and urban landscape planning for two centuries. The proposed typology of allées based on complex functional and aesthetic-visual aspects explains why and how this special garden element became an elementary space-forming tool in landscape architecture, landscape planning, and urban development beyond garden art. Their main functions include connectivity, the building of visual links, directing and helping movement in open landscapes, and creating living, green space walls that offer protection against wind, dust, snow, and sunshine. On the other hand, the beauty of trees and the enrichment of the landscape with tree-lined roads and streets in either the rural or the urban landscape are all essential benefits called ecosystem services in the contemporary theory of green infrastructure.

\section{Discussion-Allées and the Heritage Concept}

Based on the analysis of Hungarian Baroque garden art creations, the compositional function of allées can be confirmed to be fundamentally similar to the garden art of the French absolutist André 
LeNôtre who strove to create a powerful perspectival effect by allees framed in an architectonic form in Vaux-le-Vicomte and Versailles. The allées laid out along the visual axes resolved the boundaries of the gardens and embarked on a journey of conquest as a characteristic Baroque tool for garden art. Beyond the primary compositional purposes, the Baroque allées of the 17th and 18th centuries had multiple functions, such as framing parterres, casting a shadow on garden esplanades, providing visual guidance to travelers and enabling the safe utilization of roads. Realizing this functionality, even landscape gardens did not necessarily cease to use allées; however, a series of allées disappeared during the construction of landscape gardens. On the other hand, allées gained much importance after the afforestation of the main transport roads created by Napoleon and in the process of urban reconstruction in Europe from the middle of the 19th century [A12]. Allées are accepted as multifunctional design instruments in landscape architecture [20]. "Rows of trees planted along country roads fulfilled not just practical purposes but also a deep-seated aesthetic impulse, just like Baroque allées and urban boulevards" [19].

\subsection{Historic Gardens and Allées as Planned and Maintained Living Heritage}

The transience of garden art pieces is evident if we think about the development cycle of the main material, i.e., vegetation, mainly that of trees. The life expectancy of different species is mostly determined by habitat and ecological conditions, the given ecosystem's environmental loads, and the quality of maintenance and care. Similarly to architectural creations, gardens and parks often fall victim to changes in styles, ideas, functions, and ownership. This is especially true of Baroque gardens, which, in many cases, disappeared from the palette of European garden art as a result of the alteration in the conception of nature, the loosening of the social hierarchy, the modification of power and economic relations, and the tremendous building and maintenance costs associated with this sort of architectonic garden space formation $[7,20]$ [A13]. Baroque gardens not only became old-fashioned artistic pieces during the second half of the 18th century in Europe, but they were also seen as unnatural, affected creations. Foreign travelers visiting Eszterháza at the end of the century referred to the garden by putting on fastidious airs [8] (p. 104). Surviving Baroque garden art pieces are scarce throughout Europe, and saving them is obviously important from the points of view of cultural history and garden art.

The institutionalized form of monument preservation gained strength during the twentieth century. The international guidelines on the importance, possibilities, and methodology of the conservation and restoration of historic buildings were established by the Venice Charter in 1964 . The creations of garden art were also at the center of interest in monument preservation and, finally, in 1982, the Florence charter on historic gardens was published. While the principles of and methods for the preservation of historical gardens have been declared, the protection of special historic garden elements such as allées has not received much attention in recent decades. However, regulatory protection of allées and avenues or tree-lined roads does exist in some European countries. In France, Luxembourg, Latvia, and Belgium, the protection of allées is established on a voluntary basis [21]. In Hungary, the protection of allées is regulated at two levels, similarly to the regulation of nature conservation and landscape protection. Both the Venice and Florence charters place emphasis on the possibility of authentic preservation and the specialness of living heritage. However, the visual and characteristic changes due to the growth, development, and aging of tree canopies still raise many questions about the overall requirement of authenticity.

There are no generally applicable solutions, procedures, or formulae for the preservation of allées. Every location and every allee creation is unique; therefore, renewal requires the elaboration of an individual methodology based on scientific research, an on-site survey, and measurement of the health condition of trees to help with decision-making in the case of old or truncated trees. The safeness aspect should have a high degree of importance when the allée belongs to a publicly visited garden or site. Even the principles of preservation summarized in the Florence charter should be revised due to the dramatic ecological changes these pieces of living heritage currently face. Climate change and the spread of new diseases and pests may adversely affect both the mature vegetation and the newly 
replanted trees. Article 12 of the Florence charter [A14] emphasizes the importance of authenticity in the planting design of a renewal project. In the case of Baroque gardens, a change in the planting design may result in a definitive alteration of space forms and proportions as well as the landscape's character. Still, there might be situations when a change in planting material cannot be avoided [3]. On the other hand, the Florence charter also stresses that the contemporary functions and the possible level of maintenance of the garden complex are to be considered when deciding on an approach to authentic renewal. Allees that were pruned in the Berceaux form during the Baroque period might be impossible to restore due to the required level of maintenance. Again, the character of the allee might be different even though the visual stress, the bordering, and other functions could be reconstructed.

In the case of allées that remain as a form of living heritage of the Baroque era, a change in a garden's architectural character is inevitable when part of the original tree canopy falls [A15]. A basic aesthetic requirement is to preserve the integrated image of the allée because the visual essence lies not only in the artistic nature of single specimens but also in the uniform appearance of the entire ensemble. If an old allée contains original, albeit age-worn, specimens or the ensemble is full of hiatuses or overly truncated torsos, any decision is always hard to make. Do we have to plant young trees in the empty spots and replace in this way the old specimens, or we should renew the entire allée, even if it means felling the still-viable, albeit old, trees, which would inevitably raise ethical issues? [20,22] On the other hand, the rarity or the genetic value resulting from the age of trees might be considered to be a decisive factor in the selection of a renewal method [4].

\subsection{Heritage of Baroque Allées in Hungary}

Almost all Baroque gardens in Hungary have been reconstructed in the landscape style since the final decades of the 18th century and, as a result, these architectonic, clipped, and pruned gardens and high hedges have disappeared. Most of the allées that survived have a landscape scale, are located alongside the road and mark estate boundaries, or were assumed to be important due to their space-bordering function within the garden. We can find examples of the former in Eszterháza and Nagycenk, while the upper garden of Gödöllo can be mentioned as an instance of the latter case. Unfortunately, the list is not very long, because even the allées beyond the estate boundaries were no longer needed in cases where the cultivation or land use method was changed or where the urban development expanded to the borders of the Baroque gardens.

The fate of the Hungarian castles and castle gardens after World War II was sealed after the communist transfer of power. They became abandoned (at best) after they were confiscated, put under state control, or fell victim to senseless destruction. Besides forced industrial expansion, not much attention was paid to the preservation of architectural and garden art values. The onetime estates were utilized for irrelevant functions and the buildings were transformed into industrial units, education, health, or public administration institutions, or agricultural cooperatives, while former gardens often fell victim to the development of residential or sports areas or road widening and construction.

The preservation of the surviving elements of Baroque allées-from the perspective of around two and a half centuries-is a special monument preservation task. In Hungary, the number of garden art pieces listed as historical gardens is relatively low. Most of the surviving gardens are subject to local or national nature conservation regimes that mainly emphasize the natural value and not the landscape architecture's importance. In certain cases, the garden art heritage in Hungary is subject to double protection, which may cause conflicts due to the different emphases placed on monumental landscape architectural conservation and renewal and the natural values associated with it. This issue is especially relevant to allées, where the firmness and rhythm of the architecture gradually disappear by the ageing or falling of trees. Careful maintenance of the allee and making up for any hiatuses may secure the continuity of the living closure but damage the rhythm [20]. If the number of trees falls below $50 \%$ of the original population, it is worth considering the renewal of the entire allee. In the case where the creation of the allee is related to a personality of historical or cultural significance, 
and if the tree taxon can be considered to be valuable, then a genetically identical renewal might be recommended that is able to preserve the intrinsic and genetic value in its entirety.

\subsection{Exemplary Renewal Methods and Plans for Baroque Allées in Hungary}

Three Baroque allées can be mentioned in this respect. The horse chestnut tree allée located in the upper garden of the Royal Palace of Gödölló is an example of the framing, bordering allée type. The Széchenyi lime tree allée in Nagycenk is a landscape-scale creation. The triple allées pruned to form a vault in the castle garden of Eszterháza in Fertőd had a dual function: they served as the space-bordering tree canopy in the ornamental garden and led the way to the goosefoot vues of the game preserve and the hunting wood.

\subsubsection{The Baroque Horse Chestnut Allée in Gödöllő}

The Grassalkovich Palace in Gödöllő was funded by Antal Grassalkovich I. This characteristic palace became a prominent and trend-setting type of 18th-century Hungarian Baroque building architecture. From the original garden elements, the horse chestnut allée with its bordering function has been preserved despite repeated reconstructions (Figures 15 and 16). During the reconstruction in the 1810s, the garden was transformed into an early landscape garden, and the almost 400-meter-long straight line of the Baroque allée was loosened in the garden view by gently curved shrubbery to harmonize it with the landscaped garden's character [18].

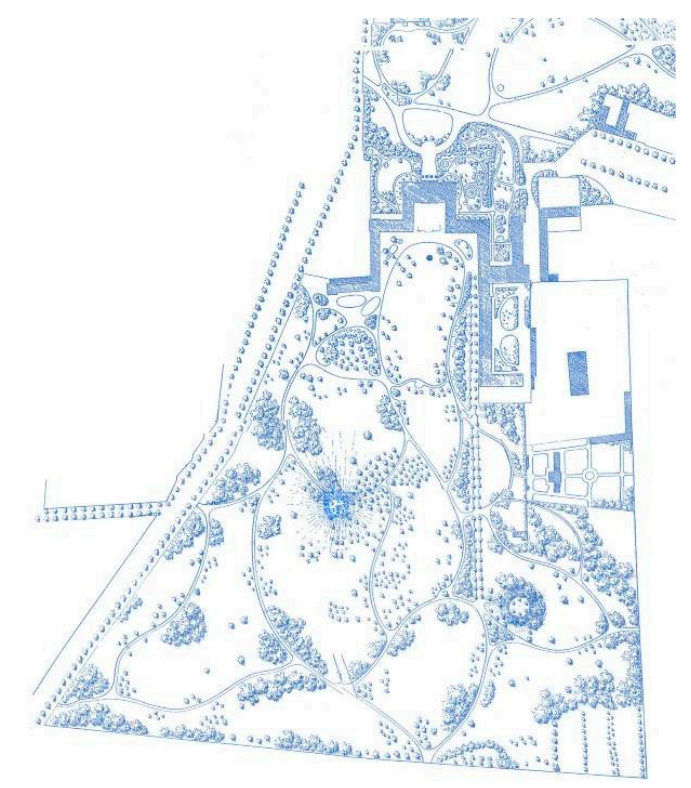

Figure 15. The upper garden of Grassalkovich Palace in Gödölló in the reconstruction plan of 1867. The plan's objective was to create a romantic landscape garden with the Baroque allee fitted into the loose space forms.

In 2000, after a decades-long period of devastation, the architectural reconstruction resulted in the renewal of the central wings for museum and cultural functions. The garden's renewal was started in 2008 with the reconstruction plans for the pleasure garden in the upper garden in about a 10 ha area directly connecting to the palace [A3]. An important part of this plan was the total renewal of the horse chestnut allée. Here, the trees were in a very bad, at times dangerous, condition, and in the case of the previously suggested substitution-type reconstruction, the image of the allee would never have been integrated, which is a requirement in the case of Baroque allées. During the renewal, the original horse chestnut (Aesculus hippocastanum) allée was substituted by a red horse chestnut (Aesculus $x$ carnea) allée, which allows for a similar allée in character and habit but has higher resistance to the horse 
chestnut leaf miner that is generally propagated in Hungary [A16]. The allée's renewal was carried out according to the original planting system [18].

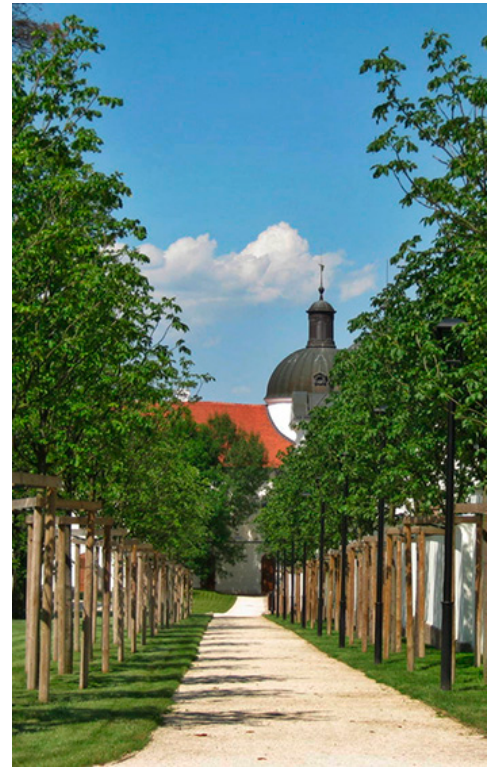

(a)

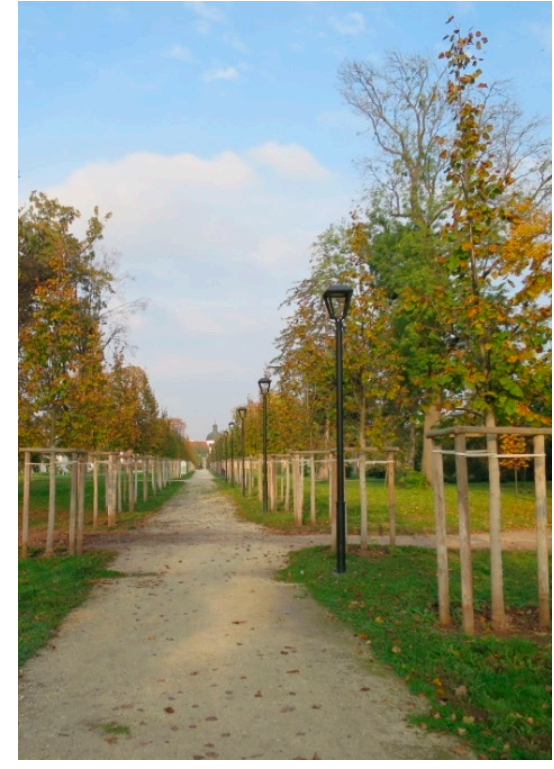

(b)

Figure 16. (a) The renewed horse chestnut allée was still in good condition in 2012 even though some trees already showed signs of disease. (b) The replanted, renewed allée of lime trees has restored the historic garden element but with a different character. Autumn, 2018.

The renewal plan for the upper garden and its Baroque allée was adapted to the spirituality of the almost 300-year-long history of the garden. This could be interpreted as an additive development since, in the case of all reconstructions and extensions, the preservation of valuable and old garden elements is an important principle. Throughout the renewal, the most important image shift occurred in the canopy mass and the flowers' color; however, this seemed to be rather beneficial since the new taxon's canopy size fitted better to the given spatial limits and the attractive, colorful blooming added to the ornamental value. In this way, the method for the allee's renewal was not a species-authentic but a genus-authentic method. Such a change in planting material is not rare according to exemplary European renewals [16] [A17,A18].

Unfortunately, the once-successful allée renewal turned out to be a disaster within a short period of time. The Aesculus $x$ carnea sapling trees arrived from a German nursery as no Hungarian tree nursery could supply the necessary quantity of 98 trees. Unfortunately, in two years' time, some of the trees started to badly weaken. A medical survey of the trees diagnosed a serious bacterial infection (Pseudomonas syringae pv. aesculin or chestnut bleeding cancer), which is an alert disease and no such infection had been reported in Hungary until then. Despite three years of urgent and careful desperate medical treatment, the allée had to be declared unwarrantable. Moreover, due to the risk of further infection, no horse chestnut trees could be planted in the infected area; therefore, a new taxon had to be selected. In 2014, the allée was replanted with lime trees (Tilia x europea "Pallida") that settled well and provide an increasingly beautiful view, although the character of the allée has been changed. The story of the Gödöllő horse chestnut allée is an example of an authentic type of planting design being overwritten by plant protection aspects in the context of climate change.

\subsubsection{The Genetically Identical Renewal of the Széchenyi Allée in Nagycenk}

The Széchenyi lime tree allée is a rarity among Baroque allées. The $2.3 \mathrm{~km}$ long double lime tree allée, with its striking visual axis of the former Széchenyi property, is of extraordinary importance to Hungary. Its landscape architectural and aesthetic peculiarity stems from its monumentality, 
the harmony of the landscape ensemble with the castle, and its garden. (Figure 17a) The cadaster of 2011 proved that renewal was necessary due to the slowly worsening condition of the veteran trees. Based on the survey and the aesthetic and historic importance of the allée, a new gene-identical renewal method was developed [A4]. Years passed, the condition of the allée deteriorated further due to the lack of maintenance, and finally the responsible Eszterháza Cultural, Research, and Festival Centre, by the governmental decree of 2017 on the Fertő lake World Heritage site, ordered the survey of and a renewal plan for the allée.

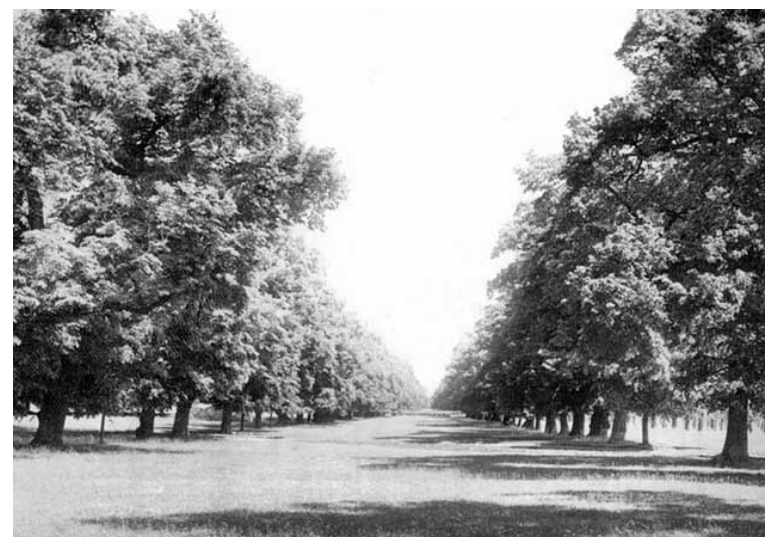

(a)

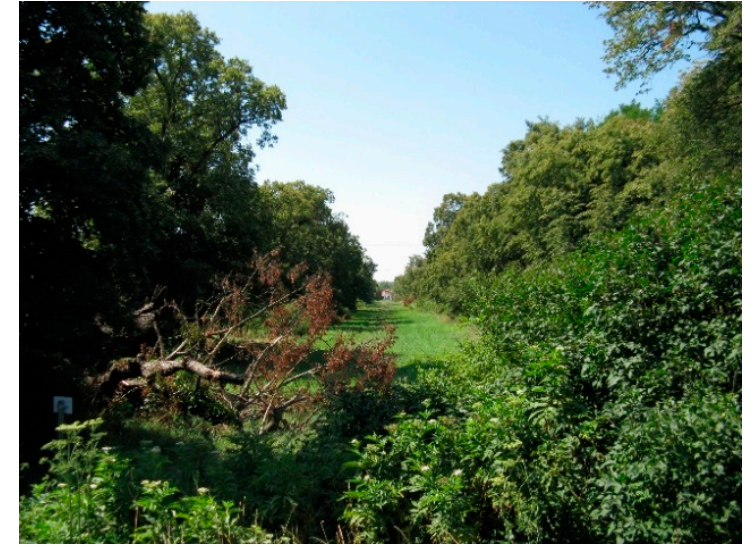

(b)

Figure 17. (a) The lime tree allée in Nagycenk in the early 20th century in a postcard. The allée of mature trees creates an imposing view. The crown of mature trees creates an almost closed space wall; nevertheless, the horizontal vue is open among the tree trunks. (b) The Széchenyi lime tree allée in 2018 appears, due to the slow dying out of the trees and low maintenance, as a forest edge rather than a Baroque landscape element. There is no horizontal vue, no transparency, and even the longitudinal vue is not characteristic.

The survey in 2018 detected a significant drop in the quality of the tree stock according to the study plan of 2011. While the number of aged trees in good condition together with aged trees requiring minor treatment was 103 in 2001, only 19 trees remained in good condition in 2018. Immediate felling had to be ordered for 73 trees due to the risk of an accident and the number of trees requiring a considerable intervention significantly increased. (Figure 17b) The plan for the long-term renewal of the allée was accepted by the commissioning company, the Eszterháza Centre. The necessary felling, the cleaning of the allée, and the treatment of the trees, which aimed to improve the condition of the old trees and the lawn esplanade, was started in 2019.

According to the historical importance of the allée, the authentic reconstruction was accepted and the propagation of vegetation was started in the autumn of 2019 and early 2020 to provide genetically identical saplings. This included the collection of seeds and fresh sprouts from the original plantation. According to the plan, a section-by-section renewal was started by using ten-year-old trees grown in the nursery of the Eszterháza castle. In the first phase, the section that is located the closest to the castle will be replanted, and some old trees in good condition will remain standing as witnesses of ages long past. Such a long-term renewal is an exceptional project in landscape heritage conservation; however, in the case of the Nagycenk allée, this is the only way to preserve the Széchenyi family's reputation.

\subsubsection{The Baroque Allées in the Eszterháza Estate Garden}

The renewal of the Eszterháza estate garden in Fertőd is important to the protection of the World Heritage Site of Fertő-Neusiedler See and to touristic developments in the region. The triple-function ensemble of the ornamental and pleasure garden, the game park, and the hunting forest, referred to simply as a "garden" in Baroque times, are interconnected by uniform ownership and spatial architectural principles. This garden complex is under state ownership today, but the development 
and maintenance tasks are performed by different service providers. The maintenance of the game park and hunting forest is the responsibility of the regional forestry service. Some areas belong to the municipality, while others appertain to public institutions or public service companies. The Eszterháza Cultural, Research, and Festival Centre gradually took responsibility for the maintenance tasks in order to renew the gardens surrounding the castle. Based on decades of research and scientific documentation, as the first phase of the renewal, a neobaroque ornamental yard and the reconstruction of the central vue in the hunting forest were implemented in 2011 [A4]. The rebuilding of the chamber gardens according to an authentic Baroque layout is in progress. Together with the plans for many other garden and park sections, the renewal of the historical allées is also to be performed in 2020 [A19].

It is not by chance that the triple allées are in the worst possible condition. The traces of pruning and clipping to create an architectural arbor shape remain visible within the deformed crown and on the knag, while, due to several cutbacks and pruning failures, the trees are more exposed to damage and they pose a greater safety risk. These two triple allées are highly deficient in trees, and the horse chestnut trees are in particularly bad condition due to the damage caused by the leaf miner insects. Renewal is urgent, but neither genetically identical nor, at least, species-identical reconstructions are to be considered because horse chestnut tree diseases occur all over Hungary. Taking into consideration the sapling stocks of the tree nurseries, the original composite plantation that provides a large flower ornament could be kept only by applying a new taxon (Figure 18).

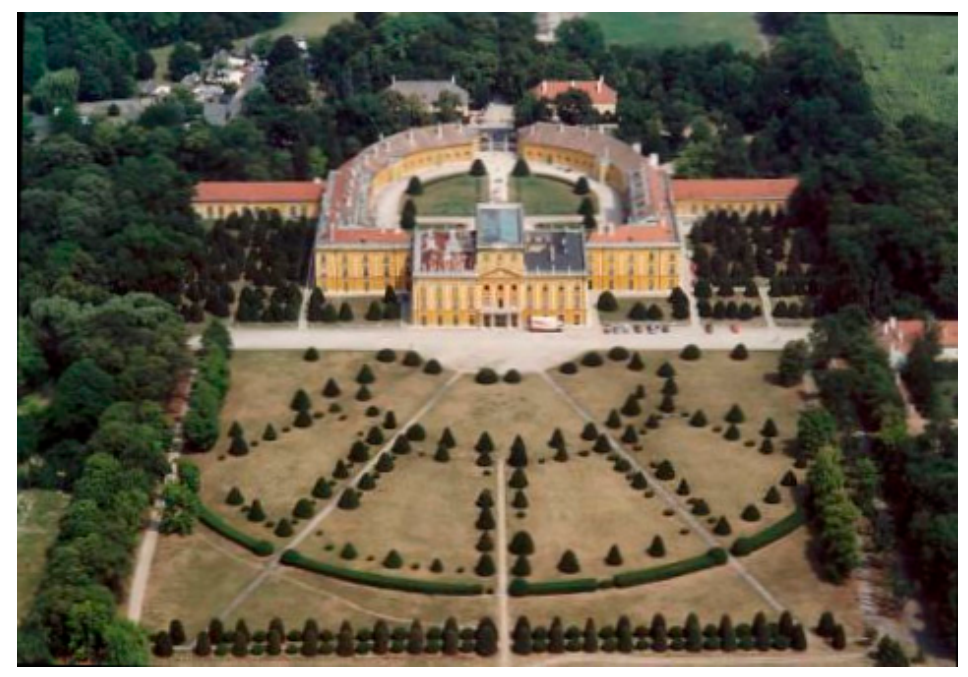

Figure 18. The triple allées of the Eszterháza gardens have lost their Baroque architectural character. The inner rows are severely incomplete and, therefore, the visual demarcation of the ornamental garden has become uncertain and indeterminate. The new reconstruction plan to be launched this year is expected to propose that the triple allées be renewed with a sectioned replantation to preserve the strong and healthy trees.

The lime tree allée (mainly Tilia x euchlora) that was planted in $2 * 2$ rows and runs along the western cross-axis is in better condition according to the analyses conducted in 2018 and 2019. Here, loss has been minimal so far, although in some cases the tree trunks are rotten. The overall character of this quadruple allée remains imposing thanks to the dense plantation system and the relatively small number of fallen trees.

The lime tree allées dissecting the side gardens and those along the main roads coming from Széplak and Süttőr are in worse condition. These allées were not pruned or clipped and the habitat is more affected by stress due to the traffic on the roads. Here, a partially resupplying, a partially sectional, or a complete renewal may be considered. 
Given the many trees in the numerous allées, a long-term renewal process is to be planned for Eszterháza by the end of this year. A special nursery should be added to the castle gardens to reflect the Baroque period, when one of the main horticultural tasks was the production of propagation stock.

\section{Conclusions}

During the development of a plan for the renewal of a historical allée-just like in the case of monument reconstruction-the question of authenticity is inescapable [6]. However, as the above-mentioned examples show, there is no universally applicable or preferable renewal methodology. In the case of living heritage, an alteration in environmental conditions, habitat, or land use can justify even the total substitution of the trees in the allée with those of a different taxon. The trees of Baroque allées have survived two and a half centuries, during which the variability in the local climate has created stressful periods for them. Even the quality of maintenance might change from time to time. Still, many of these ancient old trees remain standing, proclaiming the power of nature and the will to live. Special knowledge on how to survive is hidden in their genome. Therefore, gene-authentic propagation could be made part of the heritage conservation process too.

Trees and allées are the most impressive vertical elements and space-forming tools in garden art. On the other hand, their development into characteristic space forms may be a time-consuming process. In the case of a specific architectural garden type, such as the Baroque, homogeneity and a unified plantation system are obvious design principles. Authenticity as a general aim of reconstruction plans may require the restoration of the distant view, the character, and the spatial structure of the allée, so the visual effects of a substitution of tree species should be weighed based on heritage, monument, and environmental aspects.

It cannot be stressed enough that in the case of any renewal method that focuses on gardens, whether it be of a restoration or a reconstruction type, and especially in terms of tree stocks and allées, neither the planning nor the management can be rushed. The production of nursery seedlings and their transformation into the living tissue of the garden require many years of preparation. During the renewal of a baroque allée, it might be necessary to replace several young trees if they are planted as a replacement but are not in the right place, are in an intermediate position, or are not the right taxon; thus, the overall aim of a Baroque allée's renewal to recreate an authentic, uniform longitudinal tree canopy is not to be hurt. In such a case, the renewal plan must consider the preparatory time required for replantation.

When reconstructing a row of trees or historic gardens in general, it is always advisable to plant high-quality, pre-grown nursery seedlings or young trees so that the garden space does not remain incomplete for a long time. Replanting a centuries-old tree allée in order to replace old, very sick, distorted, and damaged trees would result in a most dramatic change in the spatial structure of the garden. For a decade or two, only the 'intention to renew' will be seen, rather than the intention to spatially reconstruct a large-scale composition. However, similar to a landlord of the 18 th century, both the designer and the customer of the restoration must think in terms of space and time. It is true that at that time the owner of the estate did not have to explain possible logging. Nowadays, communication might be a key element in the program.

The failure to renovate the horse chestnut tree allée in Gödöllo due to the serious infection in the new plantation clearly shows the problems with and even dangers of renewal of living heritage in times of climate change. We are convinced that the statements and proposals of the Florence charter according to authenticity should also be renewed, while practitioners and researchers should work hand in hand to find adequate answers to questionable traditions in planting design and planting material for historic gardens, landscapes, and allées.

"What foresight and generosity someone should have, for example in the case of the lime tree allée of Nagycenk, in order to decide to plant two rows of lime tree saplings standing $25 \mathrm{~m}$ apart from each other and extending farther than the eye can reach, under the embracing crowns of which not himself or herself would be able to walk, but a third or sixth generation" [14] [A20]. 
Author Contributions: This research was performed by the three named authors with no other substantial contribution. K.S. (Kinga Szilágyi) formulated the research aims and goals, planned the methodology, wrote and edited the paper; C.L. was responsible for materials and resources; K.S. (Krisztina Szabó) contributed to research aims and investigation, writing and review of the paper. All authors have read and agreed to the published version of the manuscript.

Funding: This research received external funding from the Ormos Imre Foundation.

Acknowledgments: We: the authors of this paper, would like to acknowledge and say thank you to the Ormos Imre Foundation for the financial support given for the publication of this article in the MDPI journal Land.

Conflicts of Interest: The authors declare no conflict of interest.

\section{Appendix A. Details and Data Supplemental to the Main Text}

A1 Imre Ormos (1903-1979), Hungarian professor of landscape architecture, director and pro-rector of the University of Horticulture, and founder of the Department of Garden Art and the university specialization of landscape and garden architecture within the horticultural engineering program in 1943.

A2 "Allee is a French term for a walk of gravel, sand, or turf, bordered by trees with branches trained to meet overhead and exclude sunlight (allée couverte)." In: Dictionary of Architecture \& Landscape Architecture. 5th ed. 1998. Penguin Books. The paper uses this term to mean single, double, or multiple rows of trees with a path, promenade, or road beside or in between them that belong to a planned and designed piece of garden art and landscape architecture.

A3 See the list of plans for the renewal of the Gödöllő Palace garden. The author was responsible for the historical research, the renewal concept, and the heritage preservation methods as a member of the team of Garden and Open Space Design, Corvinus University of Budapest, Hungary.

(a) Conceptual plan for the reconstruction of the Gödöllo Royal Castle's Upper Garden. The Department of Garden and Open Space Design, Corvinus University of Budapest was responsible for the general plan. Principal consumer: Gödölló Royal Castle Pbc. 2008.

(b) Detailed landscape architecture plan for the reconstruction of the upper garden of Gödöllo Royal Castle Section I. The Department of Garden and Open Space Design, Corvinus University of Budapest was responsible for the general plan. Principal consumer: Gödöllo Royal Castle Pbc. 2008.

(c) Detailed landscape architecture plan for the reconstruction of the upper garden of Gödöllo Royal Castle Section II. The Department of Garden and Open Space Design, Corvinus University of Budapest was responsible for the general plan. Principal consumer: Gödöllő Royal Castle Pbc. 2009.

(d) Detailed landscape architecture plan for the reconstruction of the upper garden of Gödöllo Royal Castle Section III. The Department of Garden and Open Space Design, Corvinus University of Budapest was responsible for the general plan. Principal consumer: Gödöllo Royal Castle Pbc. 2009.

A4 The site analyses and cadaster were presented by the landscape architect team of the Department of Garden and Open Space Design, Corvinus University of Budapest in the frame of a university research program in 2011. Then, in 2018, the responsible team of landscape architects of the Department of Garden and Open Space Design developed the site analyses and cadaster together with a detailed, long-term maintenance and renewal plan, coordinated by Author1 and with the participation of Author3. The contractor was the Ormos Imre Alapítvány (Ormos Imre Foundation).

A5 The ancient Persian motif flourished up to the Renaissance period in Roman and medieval gardens, and it is still often used in cloister gardens and kitchen gardens. 
A6 Bosque: a garden art term of French origin: a grove having an enclosed-foliage, small, and forest-like tree canopy with clipped foliage walls that are accompanied by garden paths, where small green spaces are created for pleasure houses, fountains, and lawns.

A7 Rotenstein, IX. 249. In: G. Győrffy, 1991. pp. 85, 99, 95-96. Rotenstein, Gottfried Edler von, known as an Austrian nobleman and traveler, was identified by Éva Balázs' research as count János Páffy, a Hungarian nobleman.

A8 In 1760, the parterre was still bordered by an arbor on both sides with double allées behind. The arbor was deconstructed around 1780 in order to provide a place for the third allee row. For the benefit of the enclosed space boundary, this triple, composite allée was clipped into an arbor form (Berceaux).

A9 In addition to the three examples mentioned below, several other castles and residences can be mentioned that included a game reserve, where the exploratory hunting grounds were arranged by installing rows of trees. This was also necessary in the case of the newly formed linear vue system, as the edge of the natural hunting woods along the clearance had to be arranged. The forest itself may form a shrubby, woody border in a few years, but planting trees can form space in a faster and more orderly manner.

A10 The term for a "game reserve" or a "game park" was usually "wild gardens" or "'asanengarten" (pheasantry) in the 18th century when the official language of Hungary was German.

A11 The cadaster was conducted by the Department of Garden and Open Space, Corvinus University of Budapest in 2011 in the frame of a two-year-long university research program on sustainable and livable landscapes. The author was the responsible manager of the research. Further details can be found in Section 4.3.2. p. 18.

A12 The renewal of the urban fabric of Paris was planned and managed by Georges Eugene Haussmann. The prefect of the city laid stress on opening wide urban avenues with double or twice two rows of trees. Well-planted urban avenues helped to increase the environmental quality of residential areas. This new form of urban open space has spread all over Europe and overseas.

A13 Only the most famous Emperors' gardens survived the revolutionary transformation into landscape gardens. The most valuable examples include Versailles and the Luxemburg in France, the Augarten, Schönbrunn, Belvedere, and Schlosshof in Austria, and the Het Loo in Holland. The Hampton Court in England could be mentioned as an exemplary case of Baroque garden reconstruction.

A14 "Those species of trees, shrubs, plants, and flowers to be replaced periodically must be selected with regard for established and recognized practice in each botanical and horticultural region, and with the aim to determine the species initially grown and to preserve them." Florence Charter, Article 12.

A15 Making up the hiatuses in an allée is always questionable because the densely populated habitat might not be favorable to young trees or seedlings planted in between the mature allée trees. This is especially true for the light-loving linden trees. Considering that linden trees are often the dominant taxon used in allées all over Europe, the single-replacement type of renewal cannot be the preferred type.

A16 The stronger resistance stems from the fact that one of the parents of the hybrid chestnut is the red buckeye (Aesculus pavia) of American origin, to which the chestnut leaf-mining moth, which attacks the common horse chestnut, is not harmful. Since the other parent is the common horse chestnut, the hybrid chestnut may show signs of damage but to a lesser extent and later.

A17 For example, the change in the tree taxon from beech to lime tree during the full renewal process for the Marlborough memorial's grand allée in the Blenheim landscape garden resulted in a significant change in the space proportions of the entire ensemble. The character of the foliage, the size of the crowns, and, thus, the entire tree canopy changed significantly. The width of the allée and the planting distance were preserved, resulting in the size of the ensemble and 
the height of the monument being disproportionate. However, the change of the taxon was an unavoidable necessity due to severe plant protection problems.

A18 A similar problem came up while preparing for the reconstruction of the Luxembourg gardens and their allées, where the tree canopy is aging. Around one-third of the tree stock is in a worrying phytosanitary state and about the same quantity was planted or replanted before 1900. Furthermore, crucial health problems, including leaf-miner infection and the new bacterial canker of horse chestnut (Pseudomonas syringae), weakened the chestnut trees. The change from Aesculus to Tilia was inevitable and it changed the character and diversity of the allées. (In: http://www.senat.fr/visite/jardin/arbres_renovation.html. (2020.08.03).

A19 The commissioning company was the Eszterháza Cultural, Research, and Festival Center. The contractor was the Ormos Imre Foundation. The Author was the responsible senior landscape architect of the survey and the conservation plan.

A20 András Balogh (1919-1992), painter, landscape architect, and professor of garden art and free hand drawing at the Horticultural University, specializing in landscape architecture and garden design.

\section{Appendix B. Source of Figures}

Figure 1a,b drawing by the Author based on historical maps of Hungary

Figure 2 MOL (National Archive of Hungary) archive of maps, the Esterházy family of Tata, MNL OL S69 No. 3.

Figure 3 MOL archive of the Prince Esterházy family, MNL OL T2 No. 1217

Figure $4 \mathrm{a}, \mathrm{b}$ published in [10]

Figure $5 \mathrm{a}, \mathrm{b}$ published in [8]

Figure 6a,b HU MNL OL T2 No.1409.; 1st military map of Hungary, 1782-1785

Figure 7a,b Published in [8]; around 1780, once in the MOL archives; Benyovszky Imre 1797.

Figure 8a,b [10]; Castle Museum of Fertőd

Figure 9a,b 1st military map of Hungary, 1782-1785; MOL Széchenyi family archive, S83 No.5.

Figure 10 1st military map of Hungary, 1782-1785.

Figure 11 1st military map of Hungary, 1782-1785

Figure 12 published in [10]

Figure 13 2nd military map of Hungary, early 19th century

Figure 14a,b 1st military map of Hungary, 1782-1785; 2nd military map of Hungary, early 19th century Figure 15 In: Conceptual plan for the reconstruction of the Gödölló Royal Castle's Upper Garden Figure 16a,b photos taken by the Author

Figure 17a,b postcard from the 1930s; site photo taken by the Author in 2018

Figure 18 Areal photo of the Eszterháza ornamental gardens and the triple allées before the reconstruction of the castle was started around 2010. Arcanum database

\section{References}

1. Ormos, I. A kerttervezés története és gyakorlata (The History and Practice of Garden Design), 3rd ed.; Mezőgazdasági Kiadó (Agricultural Publishing House): Budapest, Hungary, 1955; p. 315.

2. Divecchi, M. Evolution of Tree Landscaping in Historical Parks and Gardens. The trees of history. Protection and exploitation of veteran trees. In Proceedings of the International Congress, Torino, Italy, 1-2 April 2004.

3. Szilágyi, K.; Gerzson, L.; Bede-Fazekas, Á. The long-term preservation of an 18th century gene bank heritage-Case study of the Széchenyis' lime tree allée at Nagycenk. Appl. Ecol. Environ. Res. 2012, 10, 47-64. [CrossRef]

4. Szilágyi, K. Ethical and aesthetic dilemmas in the renewal of Historic Allées. Hist. Environ. Policy Pract. 2014, 5, 13-16. [CrossRef]

5. Jellicoe, G.; Jellicoe, S. The Landscape of Man: Shaping the Environment from Prehistory to the Present Day, 3rd ed.; Thames and Hudson: London, UK, 1995; pp. 155-158, 164-165, 207-210. 
6. Berger, E. Historische Gürten Österreichs. Garten- und Parkanlagen von der Renessance bis um 1930; Böhlau Verlag: Vienna, Austria, 2002; pp. 690-692. [CrossRef]

7. Hajós, G. Notes on the Problems of Authenticity in Historic Gardens and Parks in the Light of the Austrian Experience. J. Gard. Hist. 1995, 15, 222-224. [CrossRef]

8. Fatsar, K. Magyarországi Barokk Kertmüvészet (Baroque Garden Art in Hungary); Helikon Kiadó: Budapest, Hungary, 2008.

9. Zádor, A. A Grassalkovich-levéltár kerttervei (The garden design plans of the Grassalkovich archives). Magy. Müvészet (Hung. Art J.) 1931, 9-10, 581-598.

10. Galavics, G. Eszterháza 18. századi ábrázolásai-A kép mint múvészettörténeti forrás. (Eszterháza in the 18th century in pictures and engravings-Pictures in art history. ARS Hung. 2000, 28, 37-48.

11. Mőcsényi, M. Eszterháza Fehéren-Feketén (Eszterháza in White-Black); Vanity Press: Budapest, Hungary, 1998.

12. Mőcsényi, M. Epoches of Eszterháza; Eszterháza Kulturális, Kutató- és Fesztiválközpont, Fertőd/Eszterháza Cultural, Research and Festival Centre: Fertőd, Hungary, 2017.

13. Rapaics, R. Magyar Kertek (Hungarian Gardens); Királyi Magyar Egyetemi Nyomda: Budapest, Hungary, 1950; p. 118.

14. Balogh, A. A Tér-Idő egység stílusformáló szerepe a kerttervezésben (The trend-setting function of space and time in gardens design). Kertészeti és Szölészeti Föiskola évkönyve 1954, 18, 128-138.

15. Tiller, K.; Bond, J. Blenheim. Landscape for a Palace; Tiller, K., Bond, J., Eds.; Sutton and Oxford University Department for External Studies: UK, Oxford, 1987.

16. Blenheim Palace World Heritage Site. Revised Management Plan 2017. Historic Landscape Management Ltd. \& Nick Cox Architects. The Belnheim Palace WHS Steering Group. 2017, pp. 29, 34. Available online: https://www.blenheim.org/assets/files/images/downloads/blenheim/Blenheim-UNESCO-Managem ent-Plan-2017.pdf (accessed on 19 August 2020).

17. Szilágyi, K. The History of the Gödöllő Palace Park-The Criteria of Restoration. In Alföldy, Gábor (ed.) Királyi és hercegi kertek Magyarországon-Eszterháza, Gödöllo, Keszthely, Visegrád (Royal and Principal Gardens in Hungary) HAS Research Institute of History of Arts; Mágus Kiadó: Budapest, Hungary, 2001; pp. 85-102.

18. Szilágyi, K. Theoretical aspects for the renewal of the Gödöllő Royal Palace's upper garden. In Proceedings of the ECLAS Conference Alnarp 2008, Alnarp, Sweden, 11 September 2008.

19. Lauterbachis, I. Alleen und Wege in der Gartenkunst des 17 und 18 Jahrhunderts. Die Gart. 2006, 18, $249-262$.

20. von Krosigk, K.H. Alleen-Erhaltung und Pflege aus der Sicht der Denkmalpflege. Die Gart. 2006, 2, 303-310.

21. Council of Europe. Landscape Facets. Reflection and Proposals for the Implementation of the European Landscape Convention; Council of Europe Publishing: Strasbourg, France, 2012; ISBN 978-92-871-7079-8.

22. Pradines, C. Road Infrastructures: Tree Avenues in the Landscape. In Proceedings of the 5th Council of Europe Conference on the European Landscape Convention, Strasbourg, France, 30-31 March 2009.

(C) 2020 by the authors. Licensee MDPI, Basel, Switzerland. This article is an open access article distributed under the terms and conditions of the Creative Commons Attribution (CC BY) license (http://creativecommons.org/licenses/by/4.0/). 